\title{
The Rush to Rationalize: Public Policies and Impact Assessments
}

They came to our village and us that there would be a wonderful new development that would bring us schools and more fish and shillings and a better life. We said that we heard about the dam and that the lake would go down and that we cannot lose our fish who mostly are at the shore. We don't want the dam. They said that we were wrong and that the dam would be good for us. Then they went away. We do not know what they did after that.

[Turkana man in shoreline village following AFDB consultants' visit]

\begin{abstract}
The common interests of the Ethiopian government, international development banks and global consulting firms in promoting, implementing and legitimizing the Gibe III dam and its associated development are starkly apparent in environmental and socioeconomic studies and impact assessments. None of them address the actual impact area of the Gibe III dam project-namely, one including human and environmental effects of the project in the tri-nation Ethiopia/Kenya/South Sudan transboundary region. The Ethiopian government (GOE) downstream impact assessment is invalidated by its major omissions, misrepresentations, and fabrications. These failings include false assertions of 'disastrous' Omo River floods 'requiring' river regulation floods which do not occur; misrepresentations of Omo basin environmental hydrology and socioeconomy; and exclusion of the impacts of Gibe III dependent, large-scale irrigated agriculture. Global consulting industry assessments of the dam commissioned by the European Investment Bank and African Development Bank (AFDB) do not significantly challenge GOE failings. Instead they offer primarily 'suggestions' for future consideration, rather than the identification of analysis that must be conducted before approval of any impact assessment. They pave the way for the World Bank and AFDB to violate their own human rights protocols by funding an infrastructure to allow Ethiopia to export hydrodam generated electricity.
\end{abstract}

\section{Launching the Gibe III Dam-And a System of Bias}

Any environmental consequence has to be recognized early and taken into account in project design. (GOE 2009b)

This statement by the Ethiopian government is directly at odds with the its apparent predetermined decision that contracting and initiation of construction of the Gibe III dam could disregard the funding procedures and safeguard requirements of international aid organizations, that the Gibe III dam would be built whatever the cost to the livelihoods of the nation's own indigenous population, and that any impact assessments produced during construction would basically endorse, or legitimize the project.

$>$ The most common statements of 'justification' for the more than $\mathbf{\$ 1 . 7}$ billion Gibe III project that have been issued have been the "need for electricity" by the Ethiopian population—including its poorest elements—and the 'urgency' for regulation of an allegedly "uncontrolled" and "disastrous" Omo River. These have been repeatedly issued by the GOE (including by the Prime Minister's office, EEPCO officials and Ministers) and by development agencies involved in various stages of the project. Both statements are based on false premises. In the first instance, a high proportion of Gibe III 
power generation has been slated for export since the inception of planning. Moreover, the cost of electricity would inevitably be far too high for a vast proportion of the population. In the second, no such 'disastrous' floods exist. These issues are detailed below.

- As with the Gibe I and Gibe II projects, the GOE awarded a no-bid, 'turn-key' contract for Gibe III construction to its long-term global associate, Salini Costruttori-exempting the firm from any oversight. The GOE (with Salini) contracted two Italian-based global consulting firms for environmental and socioeconomic impact assessments. Both reports were produced in 2009. They are described below as so fundamentally flawed that they must be considered unacceptable - or invalid.

- The Ethiopian government began its construction of the Gibe III dam construction at the beginning of 2007more than two years prior to environmental or socioeconomic impact assessment. This action was in clear violation of its own laws and procedures as well as those of the international development banks from which it was to seek funding. Chapter 2 outlined the political and economic context for river basin development in prior decades within the country, including as a lead-up to the Gibe III project.

The GOE/Salini initiation of construction and after-the-fact impact assessments were done without oversight by its alleged regulatory agency, the Environmental Protection Authority (EPA) - a new agency formed under advice from international aid agencies. Directly responsible to the Prime Minister's office, under whose auspices the project had been initiated, the Authority was incapable of an 'independent' evaluation. The EPA later stated that it had 'approved' the project and repeated the Executive Office's insistence that the Gibe III dam is a matter of "national priority" and "urgency".

$>$ GOE violations of required procedures notwithstanding, the GOE requested funding from the European Investment Bank, the World Bank and the African Development Bank for its approximately USD 1.7 billion project. Despite their long-term and comprehensive support of such developments (see Chap. 2), the GOE's violation of their required procedures for consideration of funding placed the banks in a difficult position. The situation was particularly problematic since the Gibe III dam was designed as an important first phase of plans for an East Africa-wide energy network and industrial development program.

The banks continued with their means of supporting the dam, however, in multiple ways:

- Support for GOE infrastructure projects.

- Funding of Ethiopian executive and administrative agencies, including EEPCO which is directly in charge of the project.

- 'Direct funding' for "protection of basic services"- a highly fungible type of funding that is directed to the lower Omo basin, among other areas of Ethiopia.

- Funding for construction of a major transmission line (primarily by the World Bank and the AFDB) for electricity export from Ethiopia to Kenya as part of the initiation of a multi-billion dollar 'energy highway' system for eastern Africa, the EAPP. Despite declaimers The Gibe III would clearly contribute to this power export system.

The transmission line - in handling electricity from the overwhelmingly largest source of power in the Ethiopian region - the Gibe III dam - has cumulative effects with the hydrodam and therefore must be included in any impact assessment, including of the transmission line itself. No such comprehensive assessment was produced by the development banks, nor by the GOE.

$>$ EEPCO released the reports from both contracted firms in 2009. The agency released an ESIA for the dam 'project area' in January of that year: "Gibe III Hydroelectric Project, Environmental and Social Impact Assessment" (GOE 2009a). This report was prepared by the Italy based global consulting firms, Centro Electrotecnico Sperimentale Italiano S.p. A (CESI)/Mid-Day International Consulting Engineers-companies with longstanding connections to both the GOE and Salini. 'Scoping' stipulations in CESI's contract, however, limited this environmental and socioeconomic impact assessment (ESIA) to the area proximal to the dam and the 'impound area' for the reservoir. This GOE assessment effectively dismissed the possibility of serious downstream environmental and social concerns as a consequence of the Gibe III dam. 
A few of the GOE's caveat statements in its assessment are sufficient to demonstrate its disregard for the downriver impacts of the dam - certainly for the hundreds of thousands of indigenous people residing there, as well as their environs:

- There will be 'negligible impact' on livelihood bases of the population.

- There are no tribal people in the project area whose traditional lifestyles could become compromised through the implementation of the proposed hydropower project.

- No adverse direct or indirect impacts are anticipated in respect of sensitive habitats.

A second ESIA for the 'downstream zone' from the Gibe III dam was released by the GOE later in 2009. This assessment is one with extensive major omissions, misrepresentations and fabrications, the dimensions of which are indicated in Fig. 6.1. Another global consulting firm-Agriconsulting of Italy, in association with MDI Consulting Engineers-prepared this assessment, entitled Gibe III Hydroelectric Project: Environmental Impact Assessment-Additional Study on Downstream Impact (GOE 2009b). ${ }^{1}$

The omissions, misrepresentations and fabrications indicated in the figure apply to both baseline and 'empirical' information presented and are detailed in the sections below. They include, for example, the exclusions or gross distortion of:

- The transboundary character of the Gibe III's impact system, including not only the lower Omo River basin but Kenya's Lake Turkana region, and the contested Ilemi Triangle Region with the extreme southeastern portion of South Sudan.

- Major seismic issues in the Gibe III dam region, including plausible catastrophic destruction from earthquake and landslide events.

- Fundamental hydrologic characteristics of the region, especially the Omo River's flow volume and Omo River inflow to Lake Turkana - and the impacts of their radical reduction from the effects of the Gibe III dam and the large-scale irrigated agricultural systems planned, the characteristics of multiple watercourses in the lower basin, and the nature of Omo River flooding patterns.

- Hydrologic patterns of Lake Turkana and critical freshwater inflow from the Omo River.

- Livelihood systems of pastoral, agropastoral and fishing ethnic groups within the lower Omo River basin and around central and northern Lake Turkana: their customary resource tenure patterns, present economic status, and vulnerability to radical destruction of their survival systems from river and lake reduction by the Gibe III dam.

\section{The Myth of Flood 'Disasters' as Rationale for Megadam Development}

The crisis confronting hundreds of thousands of indigenous peoples struggling to survive along the Omo River and the shorelines of Lake Turkana is too little flooding, not excessive flooding.

$>$ The rush to rationalize the proposed Gibe III dam was starkly evident in the Ethiopian government's reports of 'catastrophic losses of human life and property (livestock, particularly) from an alleged Omo River flood "disaster" in August of 2006. The GOE's numerous reports and requests for international financial and material aid 'for relief efforts' repeatedly declared that at least 350-1000 people had drowned (depending on the specific report) and at least 3000-4000 livestock had been swept away. Hundreds of press releases and declarations from the GOE's information permeated African and international media.

The GOE has continually asserted that the "catastrophic losses" of 2006 were just the most recent of such events from the Omo River's alleged "excessive" and "destructive" flooding with repeated "major losses" of human life and livestock. Based on this fallacious assumption and the complicity of international development agencies and investing corporations, the GOE proceeded with the clear assumption that the Omo River must be regulated, and that this would occur through Africa's largest hydrodam, the Gibe III. As stated above, construction of Gibe III infrastructure was already underway in 2006, without any impact assessment.

\footnotetext{
${ }^{1}$ Unless otherwise specified, references to the GOE's environmental and socioeconomic impact assessment (ESIA) refer to the GOE's downstream impact assessment (GOE 2009b).
} 


\section{Dimensions of Invalidity: Ethiopia's Gibe III Impact Assessment}

Transboundary Impact System Ignored

- National boundaries misrepresented;

- Kenya, South Sudan, Region-wide impacts ignored

Falsification of 'Consultations' with Communities

Use of Erroneous

\section{Environmental Data}

\section{Omission of}

Large-Scale Irrigation Agriculture/ River Water Extraction

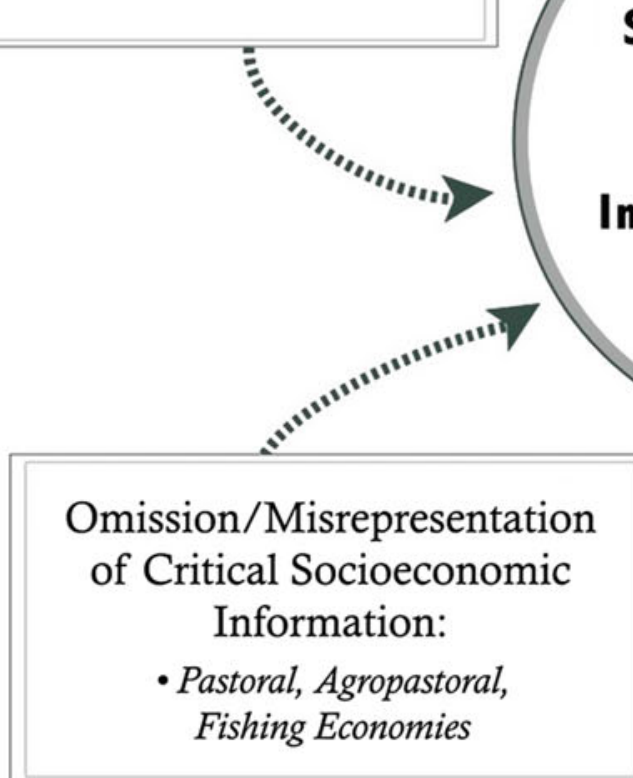

SYSTEMATIC BIAS

of

GIBE III

Impact Assessment

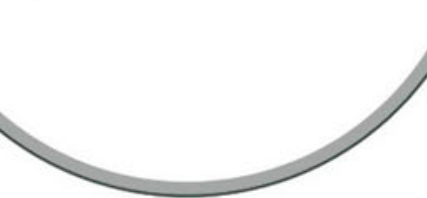

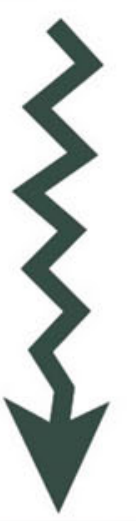

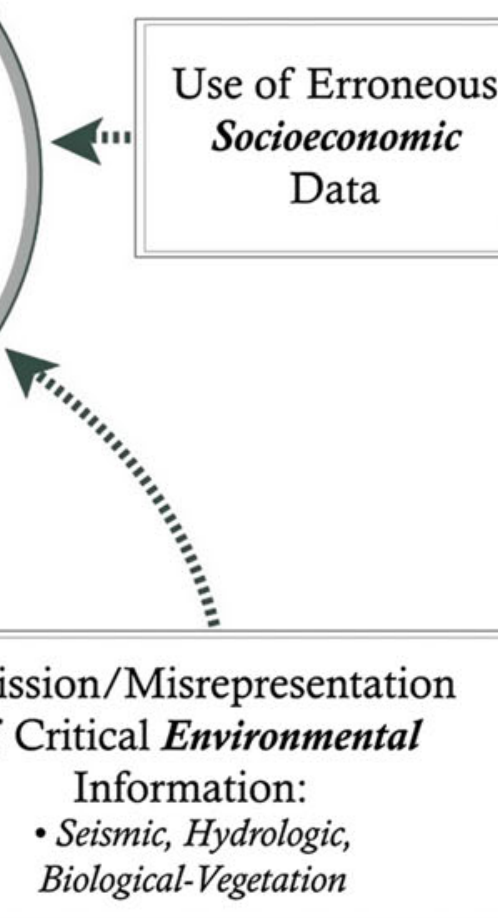

\section{Use of Erroneous} Socioeconomic

Data

\section{Invalidity of Assessment}

Fig. 6.1 Dimensions of invalidity in the Ethiopian government's downstream impact assessment of the Gibe III dam 
The GOE's false assertion of disastrous flooding caused by the Omo River is accompanied by its equally false assertion of 'excessive evaporation' occurring broadly in the region from alleged standing water following overbank flooding in broad plains adjacent to the river-with 'lost waters' that would be recovered following Gibe III dam construction. Two related assertions repeatedly made by the GOE are false.

- Firstly, regulation of the Omo River is necessary, making the Gibe III dam an imperative. In fact, no such disastrous floods have occurred, so there is no 'imperative' for major dam construction.

- Secondly, the Gibe III dam "will provide recovery" of "lost waters" from excessive flooding- "compensating' for the radical reduction of Omo River flow volume caused by the dam. In fact, only relatively small isolated pockets of standing water occur, including from seasonal rainy periods. ${ }^{2}$

The GOE maintained strict control over the reporting of the alleged flood disaster and information available to representatives from a host of national governments, international relief and development agencies, and private foundations personnel visiting the region. Visitors were situated in Omorate (where the police station and some other structures in the 20-year-old frontier town were flooded) - tens of kilometers upstream from the alleged devastation-where they were instructed by the GOE in the 'gravity of the crisis' and the 'urgent need' for substantial funds and supplies from international donors. For some, fly-overs were arranged for an aerial view of what were, in fact, swollen waters in the active Omo delta region and the Omo River's terminus at Lake Turkana. ${ }^{3}$ Inquiring visitors were told that the absence of visible dead bodies could be explained by the 'fact' that they had floated down the river and into Kenya's Lake Turkana. No explanation was offered for the absence of reports of such dead bodies or carcasses around Lake Turkana.

Hundreds of media reports repeated the same GOE 'news'-with no tolerance of dissenting views. In fact, when an Ethiopian non-governmental organization based in the Omo delta region publicly stated the absence of human life loss, it was quickly removed from the region and its agricultural aid work was discontinued.

The GOE's misrepresentation of the Omo's annual flood rests on its false assumption that massive flood waters spread throughout the plains extending east and west from the river, and upstream from the modern Omo delta.

$>$ There was no calamitous flood in 2006 - nor have there been 'repeated disastrous floods,' as overbank flooding by the Omo River occurs only within the active (modern) delta and along the delta's northernmost limit. This fact is repeatedly misrepresented by the GOE in its general statements as well as its environmental impact assessments. The absence of such flooding is clear from both abundant satellite data and accounts by indigenous community leaders throughout the so-called 'flood disaster zone'.

Omo flooding does not occur in what are in fact relict, or ancient, floodplains lateral to the river upstream from the active delta. ARWG physical scientists estimate these relict floodplains to be at least 10,000 years old. Dasanech elders also reported that according to their oral history, these lands have not flooded in recent memory. General field observation and detailed field-based studies of soil and vegetation characteristics in these broad relict floodplains-including by this writer and other ARWG researchers - have yielded no evidence of overbank flooding. ${ }^{4}$

Large portions of the Omo delta have emergent vegetation that appears in satellite photos during the highest portion of the flood. The 'submerged island' described in multiple Ethiopian press releases is an area that was emergent only in recent years, as the delta has expanded into Kenya's Lake Turkana. Its elevation is about 363 m, so it would normally be flooded

\footnotetext{
${ }^{2}$ The flooding apparent in the highly saline depression of Sanderson's Gulf (see Chap. 7 maps) indicated in the USDA satellite photos-is most likely from an ephemeral watercourse, the Kibish River - (see Fig. 1.1). Alternatively, a backup of water from the Omo's terminus could have produced these waters.

${ }^{3}$ The Ethiopian head of state, the late Meles Zenawi, made a high profile 'stop-over' in the delta region, underscoring the GOE's reports of 'calamity' in the region.

${ }^{4}$ Overbank flooding is a distinctly different phenomenon from small breaks in the natural levee at a few points, allowing movement of Omo waters at flood stage into small locales here and there behind the levee. This writer has spent weeks in these flats conducting soil and vegetation transects, as well as conducted helicopter reconnaissance throughout the region.
} 
when the lake reaches that elevation. Rather than spreading beyond the active Omo delta, the flood extended only into the northern edges of the active delta and the basin-like depression west of the Omo River, known as Sanderson's Gulf (referred to as berar by the Dasanech). The U.S. Department of Agriculture satellite photos (Fig. 6.2) substantiate this assertion, as do NASA photos from the same period.

Even the actively flooded Omo delta did not undergo the destruction claimed by the GOE. The "raging waters" described by the GOE to the media, for example, are fully contradicted by both Turkana and Dasanech fishers' accounts. Dasanech and Turkana elders interviewed by this writer and other SONT researchers gave accounts of the 2006 flood and those of prior years that are contrary to those of the GOE. SONT interviewed community elders from multiple locales in the alleged 'flood crisis' zone, including: (i) the interior of the Omo delta, (ii) the west bank of the lowermost Omo River, (iii) Todenyang/Lowarengak villages at the extreme northwestern Lake Turkana shoreline, (iv) the Ileret region at the northeastern extreme of the lake, and (v) Ferguson's Gulf (Fig. 1.3).

The Turkana and Dasanech elders consistently described annual Omo floods — and the 2006 flood in particular - in the following terms:

- The August 2006 Omo River flood was extraordinarily large, but not destructive of human life and livestock as the GOE had portrayed it. The impacts described by indigenous residents in the Omo delta and along the northernmost shores of Lake Turkana (excluding those in the service of the government) consistently described the flood as "very large" but "not destructive" - in fact, useful for their multiplicity of economic activities in ensuing months. ${ }^{5}$ The flood was not given a special name by the Dasanech or the Turkana: a clear indication that they did not regard the flood as a 'crisis'.

- Large proportions of both ethnic groups have recently been forced by their radically declining pastoral lives to relocate to the river or the lake, where they have brought their remaining livestock for 'last option' grazing and watering and where they have often taken up recession agriculture (along the Omo) or fishing, or both. They share major dependence on the annual Omo River flood whose inflow of freshwater sustains Lake Turkana and the fishery upon which they depend for their survival. The Dasanech term for 'big Omo' flood—war gudo' $h a$ '—is entirely positive for them.

The crisis that all riverside and northern lakeshore communities face is too little flooding, not excessive flooding. They regard the Ethiopian government to have brought crisis to their area-not the Omo River.

Table 6.1 summarizes the flood history as reported to SONT by 25 Turkana and Dasanech elders from villages in the modern delta region and along Lake Turkana's northwestern shoreline, who universally described the loss of human life and livestock during the 2006 flood as extremely small-ranging from 4 to 10 people lost and 5-90 cattle lost. Individual cases of humans or cattle lives lost were well known among villagers,- - underscoring these events as "special" or "news" to villagers. When told of the GOE's estimates of lost people and livestock, all informants were either angry or scoffed at such accounts.

The 2006 flood waters were not even strong enough at the mouth of the Omo River to cause many fishers to cease fishing or suffer damage to their nets and other equipment during the approximately ten day high flood waters. Villagers near the river's terminus at the lake - for example, at Lopelele - describe continued active fishing by both Turkana and Dasanech at the time. They also described the Ethio-Fisheries Corporation as remaining in the main channel for fishing during the flood. In other words, all three groups of fishers continued their activity throughout the flood's duration, while agriculturalists and pastoralists moved laterally from the river to await its return to a lower level.

- Crops were submerged, but this was universally described as an exception from the predominant experience over many years of Omo flooding, with success in recession agriculture when they were fortunate enough to receive 'enough' water.

\footnotetext{
${ }^{5}$ Individuals typically functioning in service to the government include church missionaries, both the Hiwot mission in Ethiopia and the Catholic mission at Todenyang, Kenya. Both are 'partnered' or at least complicit with the GOE's policies toward the indigenous communities and the establishment of the dam enabled irrigated agriculture along the river. During Sont investigations, both missions were charging local residents for payment of services - windmill use in the case of the Hiwot church and repair of church-installed wells (on traditional Turkana land), in the case of the Catholic diocese.
} 


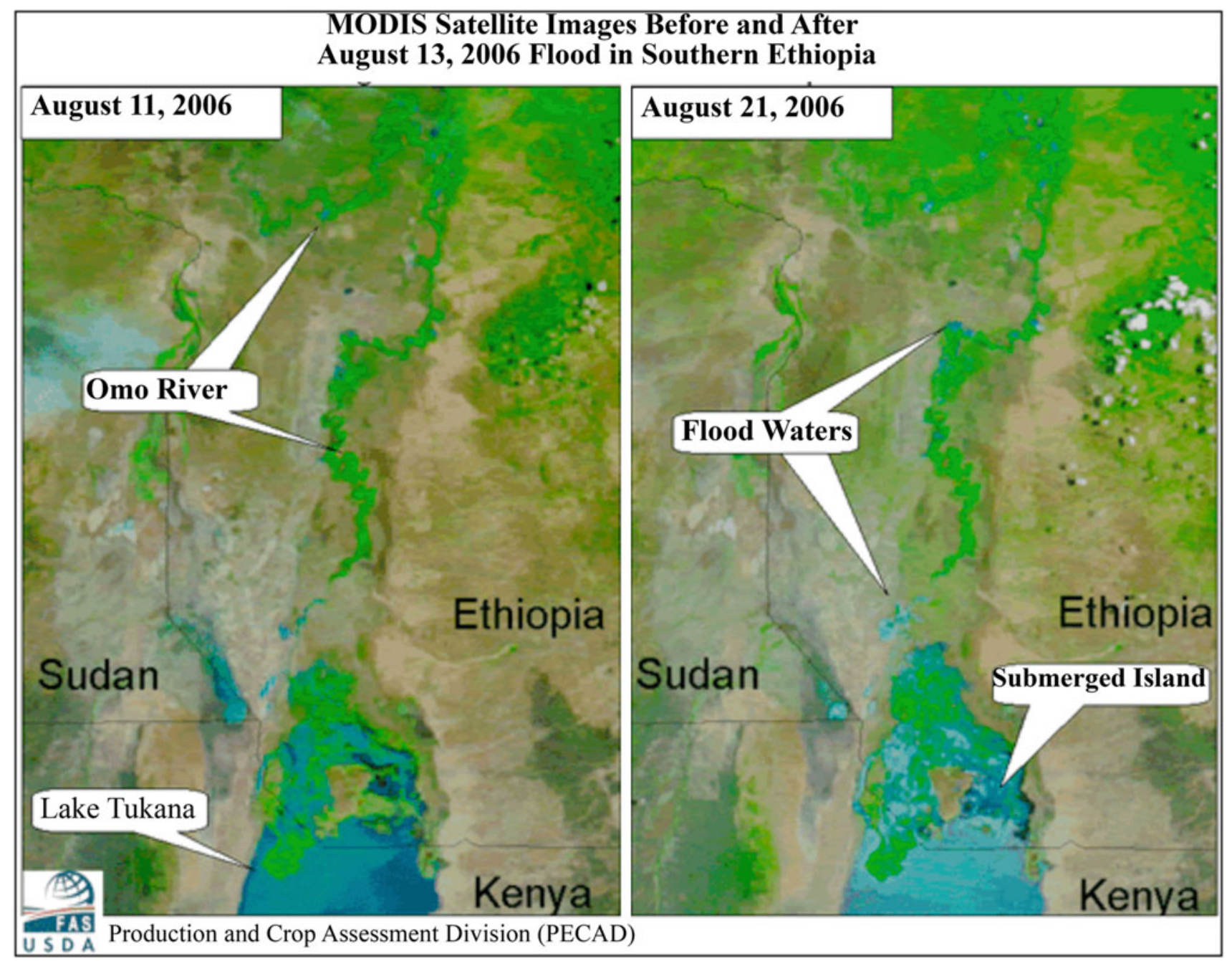

Fig. 6.2 Satellite images before and after the August 2006 Omo River flood. The photos indicate only limited areas of flooding near the Omo River and Lake Turkana, not massive scale flooding as described by the GOE. Source U.S. Department of Agriculture (USDA)

- One common account among residents was similar to that of one well-known Dasanech man considered to have a problem, because of "two dead cows - one black adult cow and one calf." The health clinics at Loyere and Toltale along the Omo also took on water, with some boxes of medicines, biscuits and other materials carried away. "That is all," local elders stated.

- Residents reported that the GOE made a powerful show of force in military terms during the flood, particularly when Ethiopia's Prime Minister visited the area. Locals described the arrival of "many engine boats," moving only a "few" people who wanted to be transported. Villagers generally knew to move away from the river with their livestock during floods. No reliable estimates exist for the population that actually moved, but elders estimate that no more than 6000 8000 people were involved.

Villagers with social ties to villages along the Omo's west bank moved there-especially to Attala, Kalama, Kipercheria, and Bokom village areas. ${ }^{6}$ Other Dasanech in the delta went to the east bank of the river, including to Afor (Afewerk) and Kapusie-locales south of Omorate where international observers were based. A small number of these new settlements

${ }^{6}$ Many of these Dasanech had to flee Atalago the following year, due to hostilities with the Turkana. 
Table 6.1 Recent Omo River flood history from a SONT 2009 survey of village elders

2009 SURVEY OF WESTERN OMO DELTA \& NORTHWESTERN TURKANA
VILLAGERS REGARDING RECENT FLOOD HISTORY (25 RESPONDENTS)*

\begin{tabular}{|c|c|c|c|c|c|}
\hline YEAR & $\begin{array}{l}\text { FLOODS } \\
\text { 'SERIOUSNESS' }\end{array}$ & $\begin{array}{l}\text { DELTA } \\
\text { COVERAGE }\end{array}$ & AMT.DELTA/WEST & $\begin{array}{l}\text { CATTLE } \\
\text { LOSS } \\
\end{array}$ & $\begin{array}{l}\text { GOATS/ } \\
\text { SHEEP }\end{array}$ \\
\hline 1968 & BIG floods & $\begin{array}{l}\text { Covered all } \\
\text { the delta }\end{array}$ & $\begin{array}{l}\text { West channels were } \\
\text { full }\end{array}$ & $\begin{array}{l}\text { Small } \\
\text { losses }\end{array}$ & $\begin{array}{l}\text { No } \\
\text { reports }\end{array}$ \\
\hline 1986 & Normal floods & Full deltas & & n & 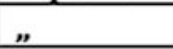 \\
\hline 1987 & Little floods & $\begin{array}{l}\text { Little to the } \\
\text { deltas which } \\
\text { had already } \\
\text { started to dry }\end{array}$ & $\begin{array}{l}\text { Gave room to } \\
\text { Dasa...to move } \\
\text { forward to the deltas }\end{array}$ & no & no \\
\hline 1988 & Low inflow & $\begin{array}{l}\text { Little } \\
\text { coverage }\end{array}$ & $\begin{array}{l}\text { West channels a half } \\
\text { full/deltas }\end{array}$ & $"$ & $"$ \\
\hline 1993 & No impact & $\begin{array}{l}\text { Small flow } \\
\text { into delta }\end{array}$ & $\begin{array}{l}\text { West channels were } \\
\text { full; others lacking }\end{array}$ & $"$ & $"$ \\
\hline 1994 & Small inflow & " & " & " & n \\
\hline 1995 & Too little. & $\begin{array}{l}\text { Didn't reach } \\
\text { most of delta }\end{array}$ & Very small & $"$ & $"$ \\
\hline 1996 & $\begin{array}{l}\text { The deltas got } \\
\text { enough. }\end{array}$ & full & Normal & $"$ & $"$ \\
\hline 1997 & " & , & , & ” & ” \\
\hline 1998 & $\begin{array}{l}\text { Floods that up } \\
\text { rooted reeds } \\
\text { that covered the } \\
\text { whole part of the } \\
\text { lakeshores. }\end{array}$ & $"$ & $"$ & $\begin{array}{l}\text { Unknown } \\
\text { number }\end{array}$ & $"$ \\
\hline 1999 & Small floods. & $\begin{array}{l}\text { Extremely } \\
\text { small }\end{array}$ & Very limited & no & no \\
\hline 2000 & ” & $n$ & $n$ & $n$ & " \\
\hline 2001 & moderate & $\begin{array}{l}\text { Moderate } \\
\text { coverage }\end{array}$ & $\begin{array}{l}\text { Covered the deltas to } \\
\text { west channels. }\end{array}$ & $"$ & $"$ \\
\hline 2002 & Very very small & $\begin{array}{l}\text { Small inflow } \\
\text { inside the } \\
\text { river. }\end{array}$ & Very small & $"$ & $"$ \\
\hline 2003 & Very small & $\begin{array}{l}\text { Little out but } \\
\text { most the } \\
\text { river }\end{array}$ & $\begin{array}{l}\text { Very small to the } \\
\text { channels in the west. }\end{array}$ & $"$ & $"$ \\
\hline 2004 & & " & , & , & , \\
\hline 2005 & , & , & , & , & , \\
\hline 2006 & $\begin{array}{l}\text { Lasted 6-9 days } \\
\text { lasted five to } \\
\text { eight days. }\end{array}$ & $\begin{array}{l}\text { Mixed with } \\
\text { rains which } \\
\text { caused } \\
\text { additional } \\
\text { water in } \\
\text { streams to } \\
\text { enlarge, so } \\
\text { people } \\
\text { moved aside. }\end{array}$ & $\begin{array}{l}\text { Full water to both } \\
\text { west channels and } \\
\text { deltas. Fishing } \\
\text { continued, villagers in } \\
\text { delta moved to } \\
\text { shores. Several } \\
\text { people drowned } \\
\text { trying to retrieve } \\
\text { animals. }\end{array}$ & $\begin{array}{l}50-90 \\
\text { lost; } \\
\text { 'stuck in } \\
\text { mud' } \\
\text { along } \\
\text { river; }\end{array}$ & $\begin{array}{l}\text { No } \\
\text { reports, } \\
\text { but same } \\
\text { as cattle. }\end{array}$ \\
\hline 2007 & Big floods & full & $"$ & no & $\begin{array}{l}\text { No } \\
\text { reports }\end{array}$ \\
\hline 2008 & No impact at all. & $\begin{array}{l}\text { Normal } \\
\text { coverage }\end{array}$ & No coverage & $"$ & no \\
\hline
\end{tabular}

* Terminology used by SONT interviewers and by respondents are retained in this table.

Elders interviewed were from Dasanech villages within the Omo delta and Turkana villages along Lake Turkana's northwestern shoreline. 2009 survey of western omo delta and northwestern Turkana villagers regarding recent flood history (25 respondents) (Terminology used by SONT interviewers and by respondents are retained in this table) 
were perpetuated after the flood. Some of the newly settled villagers were incorporated as 'paid' labor on government farms, while others attempted to survive on their own or migrated back into the delta region or off to the east bank of the Omo. Those Dasanech who moved out of the active delta region as the Omo waters rose planned to return to their replenished lands when the waters subsided, as usual. However, many were blocked by the Ethiopian government from doing so.

\section{Invalidity of the Ethiopian Government's Downstream Impact Assessment}

$>$ A small selection of prominent statements in the GOE's downstream impact assessment (GOE 2009b) illustrates the major failures of the downstream assessment. These issues referenced here are addressed below.

(i) Seismic Risk.

GOE Statements:

- While the Gibe III dam is located in Ethiopia, in the vicinity (about $70 \mathrm{~km}$ ) of the eastern branch of the East African rift system the entire area interested in the project, according to the Level 1 Design Geological Report, doesn't show any evidences of present existing seismic activity.

- There are no confirmed occurrences of geothermal activity in dam area and because of its distance from the major Ethiopia seismic centres, located in the rift valley; any tectonical [sic] event will have negligible effects on the project area.

False. Historical records and current geophysical information freely available in the public domain do not support these statements. As Chap. 3 details, there is a $20 \%$ chance of a 7 or 8 earthquake within the Gibe III dam region within the next fifty years, and there has been significant seismic activity within the correct geographic unit of concern, as established by international standards. Moreover, there is clear evidence that earthquakes of a magnitude greater than 5, accompanied by a long series of foreshocks and aftershocks, have been related to reservoir impounding.

To repeat the statement by an ARWG geologist researching volcanics in river basins for several decades:

In the case of Vaiont, Italy, accelerated mass movement displaced water in the reservoir, the water overtopped the dam, and a 226-foot wall of water drowned some 2600-3000 people downstream along the Piave River. Such an event in the Omo would obviously affect a great many more people, most likely tens or hundreds of thousands of people.

(ii) 'Elimination of Drought Risk'. GOE Statements:

- The main beneficial impacts of the Gibe III reservoir operation on the downstream hydrological regime are, therefore, as follows: ... Reduction of the extended drought periods (as the 1986-1987 ones). The [Gibe III] plant will allow the complete regulation of the river flows reducing the highest peak floods and avoiding extended drought periods...

- [Artificial floods] nearby Lake Turkana will be similar therefore to the monthly average flows of August/September during the dry years thus avoiding any critical drought event.

- Floods that occurred in 2006 (with return period of less than 10 years) caused destructive effects on human and animal life, private assets and public infrastructure in the river delta, while the extended drought[s] period 1986-1987 originated a famine crisis for humans and wildlife. The [Gibe III] plant will allow the complete regulation of the river flows reducing the highest peak floods and avoiding extended drought periods by means of: ...The reservoir live capacity of 12,300 $\mathrm{mm}^{3}$ (Comparable to the mean annual inflow volume of 13,800 $\mathrm{mm}^{3}$ )...

- Increase in the Omo River's flow volume during the dry season (by dam engineers, following the construction of the dam), will alleviate the "severe drought" and associated overgrazing conditions in the lower basin.

False. Droughts are the result of lack of rainfall, not river flow volume. There is no causal relationship between volume of river flow during the dry (or wet) season, on the one hand, and drought conditions within the extensive rangelands of the lower Omo basin on the other. The EIA's assertion that there would be a carefully regulated flow that would alleviate grazing conditions is also unfounded. Overgrazing results from a complex of changes, including territorial restriction of indigenous 
groups, causing overcrowding of livestock. The reverse is overwhelmingly likely to occur: precipitous drop in river flow would radically reduce available pasturage and browse near the river and force major overgrazing and even worse hunger conditions throughout the region. The following chapters detail these issues.

(iii) Kenya's Lake Turkana Level.

GOE statement:

The Gibe III dam will stabilize, not lower, the present level of Lake Turkana. No appreciable drop in lake level or constitution will result from the dam's construction.

False. Dam completion, reservoir filling and early dam operation, would produce a substantial drop in the level of Lake Turkana-by ARWG scientists' estimate, at least $7 \mathrm{~m}$ within 5 years-or about a $60 \%$ reduction of flow volume; higher estimates extend to anywhere from 10 to more than $20 \mathbf{~ m}$. A $2-4 \mathrm{~m}$ drop in the lake level, calculated purely from the volume of water required for reservoir fill, is improbable, in view of:

- The high frequency of fissures in the basalts at the reservoir, with major potential seepage from the reservoir (which would take decades or longer to reach Lake Turkana) and

- Major abstraction of water for planned large-scale irrigated commercial agriculture and industrial development.

\section{(iv) 'Excessive' Flooding and Evaporation.}

The GOE's ESIA makes more than fifty references to alleged repetitively occurring 'destructive floods', including the supposedly 'disastrous' flood of 2006. Its statements include:

- Large and sudden floods (peak flows up to $5200 \mathrm{~m}^{3} / \mathrm{s}$, return period 30 years, Gibe III site). Floods occurred in 2006 (with return period of less than ten years) caused destructive effects on human and animal life, private assets and public infrastructure in the river delta while the extended droughts [sic] period 1986-1987 originated a famine crisis for humans and wildlife.

Huge evaporation losses as a consequence of excessive, uncontrolled flooding [of the Omo river] further contribute to the current recession of Lake Turkana.

- Omo River overflow into the extensive adjacent floodplains, resulting in excessive evaporation, has caused the recent drop in the level of Lake Turkana ... and deprivation of vital waters for recessional cultivation.

- The Gibe III dam will provide for 'recovery' of these waters, thus compensating for much of the river flow volume decrease during reservoir filling.

- The long-term benefits [of the Gibe III dam] will include the reduction of the unproductive evaporation losses taking place in the floodplains after the floods retreat. These losses largely exceed the expected total evaporation from the proposed Gibe-3 reservoir.

- The Omo River, in fact, provides over $80 \%$ of the lake water resources. By retaining the unproductive runoff surplus of the extreme high-flow years in the reservoir, and releasing it in the extreme low-flow years, the dam will secure an overall increased inflow to the Lake.

False. There is no 'excessive flooding' or 'excessive evaporation' in the 'floodplains,' as these broad mudflats are relict, not active floodplains - thus, there are no such 'benefits' of the Gibe III dam. There is no such cause of the recent drop in the level of Lake Turkana, nor is there any 'withholding' of waters from cultivated lands. Flooding has never been controlled, yet Lake Turkana has risen and fallen significantly in the past fifty years; the floodplain has played no role in the lowering of Lake Turkana. The sharp drop in lake levels in recent years results from reduced precipitation in the large upper Omo basin (more than $200,000 \mathrm{~km}^{2}$ ). As detailed in the next section, there has been only one major flood within the past fifty years - in 2006 - and this flood was not a disaster for humans or livestock. 
(v) Indigenous 'Rationality' of Resource Use.

GOE statement:

In fact, technicalities and relevant characteristics, potentials and constraints of practiced Agriculture, Animal Husbandry and Grazing, and Fisheries have evidentiated [sic]—a largely backward and primitive concept of land use, in which natural resources are being utilized "at will” without much regard being paid to ensure any sustainability to the utilization process, in most cases simply exploiting the resource to the best of individual capabilities, given the numerous formidable constraints in terms of adverse environmental conditions in which human beings are forced to dwell. [Emphasis added]

False. The indigenous communities in the lower Omo basin have evolved highly adaptive and effective strategies for coping with some of the most difficult environmental conditions on the earth. These strategies became increasingly more difficult to implement, as powerful colonial and post-colonial economic and political forces caused dispossession and marginalization within the region. The above statement by the GOE reveals its extreme level of ignorance of the indigenous socioeconomic systems where "at will" use of resources and "disregard of sustainability to the utilization process" are completely antithetical to their centuries old traditional resource understanding and practice.

(vi) Riverine Forest and Forest Indigenous Livelihood.

The riverine forest in the lowermost portion of the Omo River is a critical settlement area and the source of livelihood for thousands of indigenous peoples_-primarily the Nyangatom, Kara and Dasanech (see Chap. 8). The GOE document falsely represents the forest as: (i) "not of unique value, since [it is] the same as the highland riverine forest," whereas the lowland riverine forest is entirely distinct from the higher altitude forest system, and it is therefore significant in Ethiopia's natural diversity; (ii) "stressed by overbank flooding by the Omo River," when no such flooding occurs upstream from the modern (active) Omo delta and its northern perimeter (Figs. 1 and 3), and (iii) benefitting from Gibe III regulation of the river. For example, it states:

The herbaceous stratum will also benefit from more limited flooding, increasing its photosynthesis activity and establishing itself on the river banks down to the river stabilized water level, thus contributing to limit riverbank erosion and filtering sediments reaching the river from the interior.

False. In reality, the opposite of all three assertions is true for this last pristine riverine forest in semi-arid Africa, with its uniquely undisturbed vegetation and rich fauna, which would be destroyed by the Gibe III dam and associated agricultural development. There is no evidence for overbank flooding, let alone 'prolonged submersion' of the forest. The riverine forest is described earlier to include a complex flora and ecology described by this writer (Carr 1977, 1998, 2012) and large fauna including leopard, elephant, buffalo, kuku, monitor lizards, at least three primate species and remarkably rich bird life. Instead the forest and woodland vegetation is adapted to and depends on soil water retention during the Omo River's annual flood for its survival. Far from benefitting, the forest would be destroyed by the elimination of annual Omo high waters during the 'flood' period since the shallow rooted forest and woodland trees are wholly dependent on soil water retention (termed 'residence time') in natural levee soils for their survival (see Chap. 8). With the destruction of this forest environment, the livelihoods of thousands of riverine dwelling indigenous residents would be dismantled.

Table 6.2 summarizes key failures of the GOE downstream assessment (GOE 2009b) for the region most impacted by the Gibe III. 
Table 6.2 Dimensions of invalidity of the Ethiopian government's environmental and social impact assessment (GOE 2009b)

\begin{tabular}{|c|c|c|}
\hline \multicolumn{3}{|c|}{$\begin{array}{l}\text { INVALIDITY OF ETHIOPIAN GOVERNMENT ASSESSMENT OF GIBE III DAM } \\
\text { IMPACTS ON TRANSBOUNDARY INDIGENOUS PEOPLES \& ENVIRONMENTS }\end{array}$} \\
\hline & $\begin{array}{l}\text { ASSESSMENT } \\
\text { COMPONENT }\end{array}$ & $\begin{array}{l}\text { MAJOR ETHIOPIAN GOVERNMENT (GOE) ASSESSMENT FAILURES: } \\
\text { (Omission, Misrepresentation, Fabrication) }\end{array}$ \\
\hline 1 & $\begin{array}{l}\text { Transboundary impact } \\
\text { system assessment: } \\
\text { (Ethiopia, Kenya, } \\
\text { Ilemi/South Sudan). }\end{array}$ & $\begin{array}{l}\text { Omission, Misrepresentation } \\
\text { Full-scale disregard for transboundary social and environmental impacts of the Gibe III dam and associated irrigation } \\
\text { agricultural enterprises. } \\
\text { • Omission of impacts of Omo River radical flow reduction on more than } 100,000 \text { indigenous (including Nyangatom, } \\
\text { Kara and Dasanech) livelihood systems along the lowermost Omo and within the modern Omo delta, as well as on the } \\
300,000 \text { indigenous population living along Kenya's Lake Turkana in the transboundary zone. All face massive scale } \\
\text { hunger, or starvation. } \\
\text { - Disregard for Kenyan sovereignty over Lake Turkana's northern shoreline zone and a significant portion of the Omo } \\
\text { delta; expansion of the delta since the 1970s brought the Omo River terminus and much of the modern delta within } \\
\text { Kenyan national borders. } \\
\text { - Omission of impacts on pastoralists of northern Kenyan and the Ilemi Triangle/South Sudan, due to loss of river-based } \\
\text { resources essential to their survival — particularly during prolonged drought periods. } \\
\text { - Omission of above changes causing major increase in cross-border interethnic armed conflict and destabilization, as } \\
\text { pastoral, agropastoral and fishing groups compete for disappearing riverine, lake and adjoining grassland resources. }\end{array}$ \\
\hline 2 & $\begin{array}{l}\text { Seismic Risk at the Gibe } \\
\text { III dam: Earthquake, } \\
\text { landslide, dam collapse } \\
\text { threat. }\end{array}$ & $\begin{array}{l}\text { Omission, Misrepresentation } \\
\text { • Misrepresentation of appropriate geographic unit for seismic analysis (identified by U.N., Ethiopian, USGS and BGS } \\
\text { seismic offices). False claims of "no serious threat," despite a } 20 \text { percent probability of a } 7 \text { or } 8 \text { (Mercalli) intensity } \\
\text { earthquake in the Gibe III dam region within the next } 50 \text { years, and plausible dam disaster occurrence with } \\
\text { landslide events. } \\
\text { - Omission of available data (e.g., literature, satellite images) indicating frequent major seismic events in the Gibe III } \\
\text { dam locality's geologically defined province. Dismissal of landslide danger, including potential danger of threat to } \\
\text { the dam's integrity. ARWG geologists point to the steep rock faces of the reservoir walls in the gorge, additional } \\
\text { landslide potential from saturation of the volcanic rocks, and seismically induced instability. } \\
\text { • Misrepresentation of sediment buildup danger as "not affecting the life capacity of the reservoir before } 130 \text { years," } \\
\text { despite counter assessment that sediment accumulation capacity would reached within a few years, with dam failure. }\end{array}$ \\
\hline 3 & $\begin{array}{l}\text { Baseline data for Omo } \\
\text { River downstream flow } \\
\text { volume \& Omo River } \\
\text { inflow to Lake Turkana. }\end{array}$ & $\begin{array}{l}\text { Omission, Misrepresentation } \\
\text { •Failure to establish baseline data/measurements for Omo River downstream flow volume, with projections of } \\
\text { 'mean flow,' instead of direct measurement of Omo flow in the lowermost basin and the river's inflow to Lake } \\
\text { Turkana. } \\
\text {-Invalid projections of existing river flow volume for both downstream zone and inflow to Lake Turkana - based on } \\
\text { incorrect/misrepresented data regarding precipitation and geomorphic characteristics of lower Omo basin, } \\
\text { including: } \\
\text { (i) Incorrectly identified precipitation regime for rainfall projections between the dam region and the lower Omo } \\
\text { basin); } \\
\text { (ii) False representation of watercourses as Omo River 'tributaries' and thus 'alternative' sources of inflow prior } \\
\text { to the main Omo channel, whereas these channels are not tributaries, as they dissipate prior to intersecting the } \\
\text { Omo River (or Lake Turkana). } \\
\text { (iii) Misrepresentation of the ephemeral Kibish River (Fig. 1.3) as flowing } \\
\text { into Lake Turkana, whereas the Kibish dissipates in a large depression (Sanderson's Gulf) northwest of Lake } \\
\text { Turkana. }\end{array}$ \\
\hline 4 & $\begin{array}{l}\text { Impacts on Inflow from } \\
\text { Omo River to Lake } \\
\text { Turkana: reduction } \\
\text { from Gibe III. }\end{array}$ & $\begin{array}{l}\text { Omission, Misrepresentation, Fabrication } \\
\text { - Misrepresentation of major components of Omo River inflow to Lake Turkana, based on above failures. } \\
\text { - Fabrication of extensive and repeated Omo flooding, with 'lost' waters otherwise available to sustain Lake Turkana } \\
\text { - whereas, in fact, these vast lands referred to are relict (ancient) floodplains not flooded for thousands of years. } \\
\text { •Fabrication (based on the above false assertion) of 'excessive evaporation' and vast floodwaters that are } \\
\text { 'recoverable' by river regulation (the Gibe III dam) - allegedly contributing to the sustainment of Lake Turkana. } \\
\text { Since there are no such waters, there would be no such 'recovery' or sustainment. }\end{array}$ \\
\hline 5 & $\begin{array}{l}\text { Excessive vs. insufficient } \\
\text { Omo River flooding re: } \\
\text { human life, livestock, } \\
\text { and habitat. }\end{array}$ & $\begin{array}{l}\text { Fabrication } \\
\text { - Fabrication of frequent 'uncontrolled' flood - 'highly destructive' of human life and livestock. By GOE accounts, } \\
360 \text { to } 900 \text { people drowned, and more than } 3000 \text { livestock were destroyed in the } 2006 \text { flood. To the contrary, } \\
\text { local elders reported very little loss of human life through drowning (fewer than } 10 \text { people and fewer } \\
\text { than } 100 \text { livestock, mostly those mired in mud). Satellite data supports local accounts of the } 2006 \text { flood. No } \\
\text { such destructive floods as described by the GOE are experienced by the region's indigenous groups. } \\
\text { - Residents throughout the lowermost Omo basin/modern Omo delta and northern Lake Turkana shoreline } \\
\text { region insist that the worst problem they face with the Omo River is too little flooding, rather than excessive } \\
\text { flooding. }\end{array}$ \\
\hline
\end{tabular}


Table 6.2 (continued)

\begin{tabular}{|c|c|c|}
\hline 6 & $\begin{array}{l}\text { Projected Gibe III } \\
\text { reservoir 'filling' period } \\
\text { and factors impacts on } \\
\text { downstream and Lake } \\
\text { Turkana people and } \\
\text { resources. }\end{array}$ & $\begin{array}{l}\text { Omission, Misrepresentation } \\
\text { •GOE exclusion of readily available geological literature and field-based information indicating highly fractured } \\
\text { basalts and other volcanic rocks at the Gibe III dam/reservoir site — indicating a high probability of major water } \\
\text { seepage from the reservoir into fractured rocks, with a major extension of 'filling' period, with sustained radically } \\
\text { reduced Omo flow. } \\
\text { - Misrepresentation of water movement in the region - re: seepage water 'returning' to Lake Turkana "in any case" - } \\
\text { whereas the alleged 'migration' of seepage waters would require decades, if not a century or more. }\end{array}$ \\
\hline 7 & $\begin{array}{l}\text { Baseline data for } \\
\text { indigenous livelihood } \\
\text { systems (pastoral, agro- } \\
\text { pastoral and fishing) }\end{array}$ & 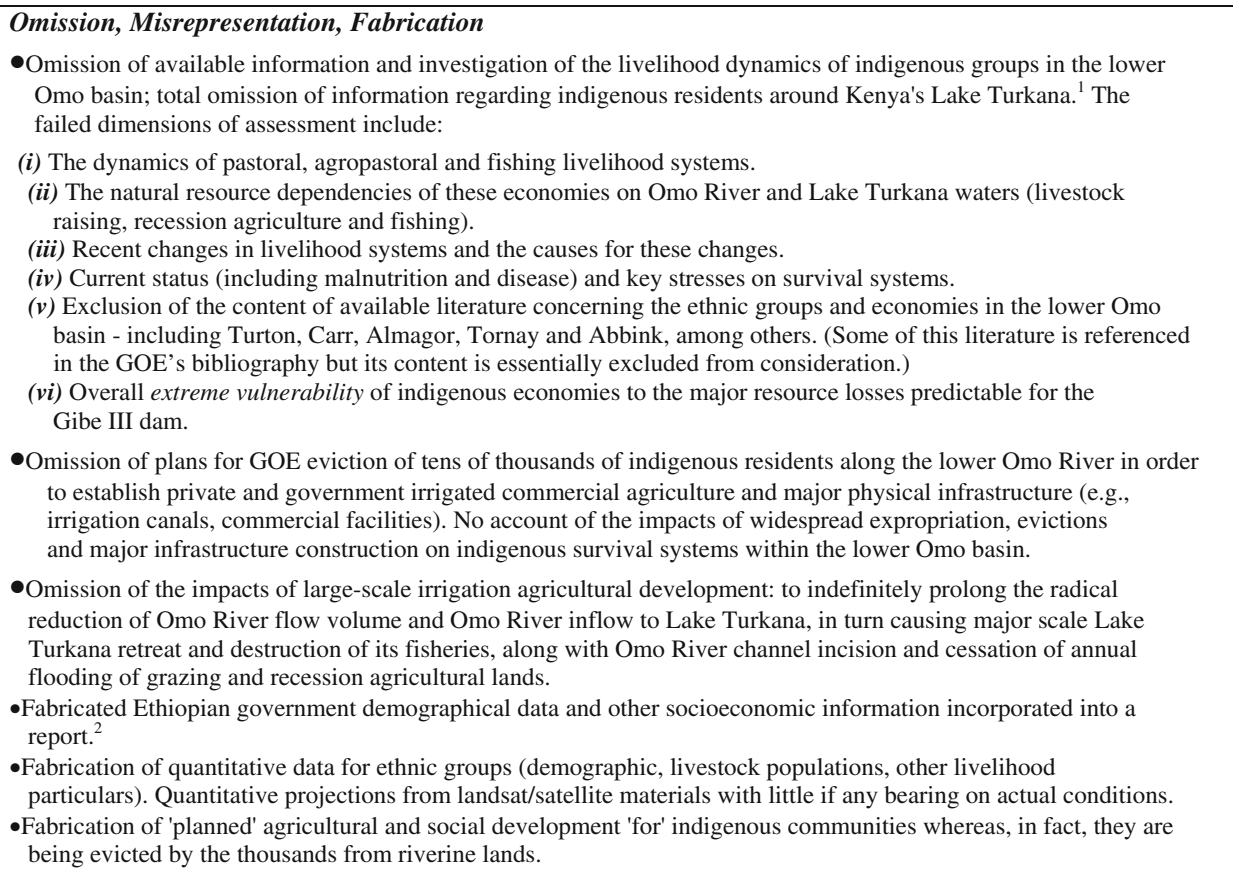 \\
\hline 8 & $\begin{array}{l}\text { Flood recession } \\
\text { Agriculture: impact } \\
\text { from the radical river } \\
\text { flow reduction }\end{array}$ & $\begin{array}{l}\text { Omission, Misrepresentation } \\
\text { - Omission of all information regarding the direct dependence of lower Omo basin indigenous communities } \\
\text { on flood recession agriculture - as well as information regarding the dependence of tens of thousands of other } \\
\text { indigenous peoples on regional exchange relations involving agricultural produce, particularly as the pastoral } \\
\text { economies of all ethnic groups continue to decline. } \\
\text { - Failure to describe accurately the locations, cropping patterns, water requirements and other specifics of flood recession } \\
\text { agricultural production, both along the Omo River's waterside flats and throughout much of the active Omo delta. } \\
\text { - As a consequence of the above failures, inability to establish any assessment of the impacts of radical Omo } \\
\text { River flow reduction caused by the Gibe III dam and dam enabled irrigation on this mainstay food source. } \\
\text { Omission of flow reduction issue, northern shoreline retreat of Lake Turkana into Kenya and desiccation of the } \\
\text { lowermost Omo flats and delta - thus eliminating flood recession agriculture in the lowermost Omo basin } \\
\text { (and riverine zone last resort grazing for livestock). } \\
\text { - Fabrication of the practice of rainfed agriculture occurrence in the Lower Basin (this practice is not possible to have } \\
\text { observed because it does not occur, due to limited rainfall). }\end{array}$ \\
\hline 9 & $\begin{array}{l}\text { Artisanal fishing in } \\
\text { River and delta: } \\
\text { Impacts of Omo River } \\
\text { flow volume } \\
\text { reduction }\end{array}$ & $\begin{array}{l}\text { Omission, Misrepresentation } \\
\text {-Failure to detail and evaluate the importance of fishing - the last resort food source for tens of thousands of } \\
\text { indigenous people in the lower Omo basin -primarily (but not only) among the Dasanech. Consequently, } \\
\text { failure to establish a baseline for considering the impacts of the Gibe III on this pervasive and increasing form of } \\
\text { livelihood. } \\
\text { - Exclusion of bathymetric and other data (available, but shown by ARWG, the EIB and others to indicate that } \\
\text { the Gibe III would cause southward migration of Lake Turkana's northern shoreline - at least a retreat of } 10 \\
\text { kilometers, but likely substantially more due to major Omo water diversion for the GOE-promoted } \\
\text { irrigated commercial agriculture). Critical fish reproductive habitat throughout the northern lake extremity } \\
\text { and delta locales would be destroyed, with elimination of the fishing livelihood as a means of survival throughout } \\
\text { the lower Omo basin (with parallel destruction of fish dependent communities around Lake Turkana). } \\
\text { - Omission of the Ethiopian government subsidized private fishing corporations active in the lowermost Omo River, } \\
\text { including the modern delta waters. Major piracy of Kenyan fisheries in Lake Turkana by the well-equipped and } \\
\text { aggressive commercial Ethiopian vessels - with the extraction of resources that are essential to both Dasanech } \\
\text { and Turkana fishers and local residents. } \\
\text { •Disregard for artisanal fishing in Lake Turkana - the mainstay of survival for upwards of } 200,000 \text { indigenous } \\
\text { Kenyans settled around Kenya's lake, as well as those depending on exchange with them (at least an additional } \\
100,000 \text { people). }\end{array}$ \\
\hline
\end{tabular}


Table 6.2 (continued)

\begin{tabular}{|c|c|c|}
\hline 10 & $\begin{array}{l}\text { Riverine forest } \& \text { forest- } \\
\text { based survival activities }\end{array}$ & $\begin{array}{l}\text { Omission, Misrepresentation, Fabrication } \\
\text { - Omission of available data regarding Omo riverine/forest ecology }{ }^{1} \text { (e.g., Carr 1998) and comparative riverine } \\
\text { environments where forest destruction has followed large hydrodam construction. } \\
\text { - No apparent field-based investigation of lower Omo basin riverine forests. Erroneous description of the riverine } \\
\text { and woodland vegetation along the lowermost Omo River. } \\
\text { - Disregard for the need to consider the Omo riverine forest structure and dependence on the river's flood regime - } \\
\text { thus its vulnerability to destruction from Gibe III development, as has occurred in all other Sub-Saharan Africa } \\
\text { semi-arid environments with riverine forest development. } \\
\text { - Fabrication of overbank floods in riverine forests: no field evidence for such exists. In order to be sustained, } \\
\text { riverine forests require particular 'residence times' of water retention in natural levee soils during the Omo River's } \\
\text { annual flood. } \\
\text { - No account of livelihood activities in riverine forest (food gathering, hunting, and bee-keeping) critical to the } \\
\text { survival of the most impoverished indigenous communities (Nyangatom, Dasanech and Kara) and tens of } \\
\text { thousands of additional pastoralists who depend on riverine environments for their own and their herds' survival } \\
\text { during prolonged drought. All would be eliminated by radical river flow volume reduction from the Gibe III dam. } \\
\text { - Omission of the GOE's major eviction of indigenous communities along the Omo River for clearing of the forest, } \\
\text { construction of canal and irrigation systems and the establishment of large-scale commercial irrigation farms. }\end{array}$ \\
\hline 11 & $\begin{array}{l}\text { Artificial flood: } \\
\text { efficacy of GOE } \\
\text { 'assurances' to sustain } \\
\text { downstream ecological } \\
\text { and indigenous } \\
\text { economies }\end{array}$ & $\begin{array}{l}\text { Omission, Misrepresentation, Fabrication } \\
\text { - Misrepresentation of GOE's 'planned' artificial flood program as calculated from adequate measures of downstream } \\
\text { river flow volume and lake inflow, when no such measurements have been taken. } \\
\text { - Misrepresentation of GOE 'planned' (but elsewhere disclaimed) artificial flooding — as "sufficient" to sustain } \\
\text { downstream ecological systems as well as to mitigate problems that "might" occur for indigenous economies } \\
\text { as a consequence of sharply reduced river flow volume. Calculations used by the GOE to bolster its assertion of } \\
\text { effective mitigation are shown to be erroneous by the EIB, the Africa Resources Working Group (ARWG) and others. } \\
\text { - Omission of the fundamental conflict between the GOE's key objective — generating hydroelectric power } \\
\text { at the Gibe III dam and that of releasing water to sustain downstream indigenous communities and their environments. } \\
\text { • Fabrication of a GOE plan to undertake controlled flooding along with agricultural development, for the 'benefit' of } \\
\text { indigenous communities, whereas a GOE program of widespread eviction and privatization of indigenous lands, is } \\
\text { well underway. }\end{array}$ \\
\hline 12 & $\begin{array}{l}\text { L. Turkana shoreline \& } \\
\text { littoral/nearshore zone } \\
\text { impacts (physical, } \\
\text { biological) of the Gibe } \\
\text { III dam. }\end{array}$ & $\begin{array}{l}\text { Omission, Misrepresentation } \\
\text { Omitted from any impact consideration, since GOE denies any significant impact will occur for the level of Lake Turkana } \\
\text { from the Gibe III dam. }\end{array}$ \\
\hline 13 & $\begin{array}{l}\text { Armed conflict and } \\
\text { crisis in the } \\
\text { transboundary region. }\end{array}$ & $\begin{array}{l}\text { Omission } \\
\text { While the GOE is fully engaged in trying to quell small scale but mounting armed conflict among ethnic groups in the } \\
\text { broader region, and neither supports or permits various peace initiatives in the region, the GOE assessment indicates no } \\
\text { cognizance whatsoever of the rising armed conflict, - conflict that would move to explosive proportions in a far broader } \\
\text { region if the Gibe III is completed, since hundreds of thousands of indigenous people would be facing the devastation of } \\
\text { their communities from the loss of the Omo River. The } 2006 \text { flood, rather than spreading beyond the active Omo delta, } \\
\text { extended only into the northern edges of the active delta and the basin-like depression west of the Omo River, known as } \\
\text { Sanderson's Gulf (referred to as berar by the Dasanech). The U.S. Department of Agriculture satellite photos (Fig. 6.2) } \\
\text { substantiate this assertion, as do NASA photos from the same period. } \\
\text { Dasanech and Turkana male villagers strongly assert that - when faced with the deaths of their women, children, and } \\
\text { youngsters to hunger and disease - they will fight for their survival. }\end{array}$ \\
\hline
\end{tabular}

Environmental and social impact assessment (ESIA)—additional study on downstream impact

${ }^{a}$ Villagers (Dasanech) throughout the west bank communities along the Omo River and within both middle and upper portions of the active Omo delta reported to SONT researchers that no individuals from the government or other agency had interviewed or questioned them about their resident populations, settlement patterns, livelihood activities (livestock raising, recession agriculture, fishing activities), or their major resource needs. Respondents described only police and government personnel taking action to move them or evict them altogether (with 'employment' of only a few individuals), or government/'outsider' presence to investigate an instance of armed conflict, most frequently with the Turkana (or Nyangatom)

bOne non-indigenous member of the governmental office stated to this writer that he himself had filled out government questionnaire forms "for" the local Dasanech population

${ }^{c}$ For details of the lower Omo basin riverine forest/woodland floristics and vegetation (see Carr 1998); some summary characteristics are presented below 


\section{The False Promise of an Artificial Flood 'Solution'}

$>$ The GOE's stated plan to begin releasing reservoir waters annually as "artificial flood" (also termed "controlled flood" or "simulated flood") forms the centerpiece of its alleged 'mitigation' program following the operation of the Gibe III dam (GOE 2009b), which the government acknowledges wouls cause a 60-70 \% reduction of Omo River flow volume. The gap between the rhetoric of the GOE's publically announced program and the reality of its actual intentions and the economic and political constraints on such a program, however, is extreme.

There is an effectively unblemished record of failure to implement artificial flood programs in major hydrodam development within Sub-Saharan Africa, despite government and development agency assurances. These failures include the Pongolapoort — one of the largest dams in South Africa, the Cahora Bassa dam in Mozambique, the Iteshi Teshi dam in Zambia, and the Manatali dam in Senegal. The Manatali Dam in Senegal is often cited as an exception to the rule of failed artificial flood programs. But even it was short-lived and ended in failure.

Assurances by governments and development agencies of planned artificial flood programs are not difficult to interpret, since large dams have produced such an abysmal record of downstream problems for indigenous communities and non-indigenous small-holders, as well as the environments upon which their livelihoods depend. Such promises of mitigation programs have served as a cornerstone for the argument that although large dams are "flawed, they remain necessary" for economic development within Africa and elsewhere in developing countries.

There are clear economic and reasons for the record of failure of these programs.

- For one thing, there is a clear contradiction between management of large dams for the maximization of power generation, on the one hand, and management geared to sustaining downstream livelihoods and riverine environments, on the other. This is evident enough in the case of Senegalese floodplain livelihoods that were sustained by the river's annual flood for centuries-until international finance and the Senegalese government constructed the Manatali. A report to the World Bank described the severe impacts of the Manatali dam on the regional ecology, agricultural production, fisheries and public health in the downstream zone. The report, by Thomas and DiFrancesco (2009) points out that inundating the floodplain below the dam:

...does require that some amount of power deliveries and revenues be foregone, as well as storage for irrigation purposes in subsequent drier years.' ... 'AArtificial] flood releases appear to have been provided only on those rare occasions when they do not result in a reduction in power revenues or irrigation deliveries. They have occurred only when the flood water could not be retained in storage in order to avoid the risks of overtopping the reservoir and creating a safety hazard. [Emphasis added]

A newly formed agency, the OMVS (Organization pour la Mise en Valeurdu Fleuve Senegal), was charged with implementing a downstream artificial flood. In order to provide the intended $2000 \mathrm{~m}^{3} / \mathrm{s}$ release of floodwaters (an amount double that assured by the GOE for the GIBE III project). The Thomas and DiFrancesco report to the World also stated:

...the necessity to release water from the sluice gate and bypass the generator, requiring the OMVS members to forego some amount of potential hydropower generation and revenues. Thus, there remains a serious economic constraint in order to operationalize the Charter's commitment to optimal annual artificial flood releases...As a consequence of these enduring trade-offs, the Water Charter, and the Operational Manual do not [sic] guarantee that the artificial flood will be provided in the magnitude and frequency that the floodplain needs...This decision is also likely to be influenced by economic and political considerations.

[Emphasis added]

The massive scale capital outlays - typically, loans to be repaid, with interest and fees-necessitate maximizing financial return from dam operations. In Africa - especially in dryland regions - this objective is hardly met by prioritizing the subsistence needs of pastoralists, agropastoralists and small-scale fishers in the downstream zone, compared with providing electricity for high energy demand industrial enterprises, whether agricultural, extractive or manufacturing. 
- Another key constraint on implementing an artificial flood program is that rainfall and its related conditions (erosion, land use, etc.) pertains to the fact that catchment area upstream from major dams are major determinants of reservoir water potential. Since these conditions fluctuate widely, and in the case of Ethiopia. are largely unpredictable, there is no possible 'guarantee' of reservoir water release to serve the survival needs of downstream peoples and their environments. Of many such instances, the Cahora Bassa dam situation provides a good example, as noted by Richard Beilfuss, hydrologist and present CEO of the International Crane Foundation:

One of the big problems with the management of Cahora Bassa dam is that each year they need to create capacity to store a possible large flood that could overtop the dam and so in order to do so they often have to release waters during dry season. Especially in wet years, they have to release waters downstream to make storage capacity available in the dam and in those dry season floods that have really been a terrible problem for farmers and fishers downstream because they can come at any time of the year. They can come in August or October and they can come and wash out crops along the lower Zambezi. It's quite a big problem, so not only is there the loss of floods during the normal time of peak flooding - there's also the potential for floods at any time of year.

$>$ There is no evidence to suggest that the Ethiopian government would be the first African nation to implement an artificial flood program for a large dam-quite the contrary. GOE spokespeople themselves - including the Prime Minister, EEPCO executives and the General Manager of Ethiopia's Environmental Protection Authority—have asserted the priority for electrical power generation in the "national interest." Even by the most optimistic scenarios set forth by the GOE, industry consultants and development agencies, such a program would not be feasible for a substantial number of years, following reservoir 'fill.' But there are direct GOE disclaimers, as well.

There are multiple disclaimers by the GOE of even its intention (or ability) to implement an extended artificial flooding program in its downstream impact assessment (GOE 2009b). These statements are ignored in the $2010 \mathrm{EIB}$ and the AFDB assessments.

They include the following:

- In the event that the annual release is not being implemented as scheduled, some possible adverse impact may occur as described below.

- Further desirable instruments have been considered and may be applied to both integrate the above main measures, compensate in case planned artificial floods are partially withheld due to unforeseen circumstances, and as desirable confidence-building actions to strengthen support of local authorities and populations.

- Some of the potential interventions meant to offset possible negative impacts stemming from possible difficulties in fully implementing designed controlled floods as planned.

- This may be necessary in case disruption of artificial floods may no longer fully contribute, by adequate submersion, to the rejuvenation of grasses.

- In case the annual release does not fully succeed as scheduled, some other compensation measures could be implemented including...conflict prevention and resolution training programs.

Beyond the electrical power allocated for marketing within the national grid system of Ethiopia, the GOE is bound by contracts for power production for export, a system of contracting fully supported by the international development banks. As detailed in Chap. 10, the banks and other key aid agencies are in fact engaged in funding the 'energy highway' system for energy transfer. Moreover, The 2010 EIB's (conservative) estimate of a USD 10 million cost per annum for an artificial flood program conflicts with Ethiopia's contracts for export of power and its debt repayment obligations.

Even if the artificial flooding plan assured by the GOE were to be actually implemented, it would be wholly inadequate to provide the flooding necessary for recession agricultural plots, riverside grazing habitat and sustainment of the riverine forest-nor would it prevent or compensate for radical retreat of Lake Turkana (see Chap. 5 and Fig. 5.2). These multi-dimensions of destruction would ensue from the outset of impoundment - a reality asserted in the 2009 ARWG report and in Carr (2012).

Finally, GOE assurances that its plan for an artificial flood program would satisfy downstream environmental and socioeconomic needs are based on a number of invalid assumptions and calculations. GOE assertions that: (i) its projections are 'analytical,' (ii) "suitable environmental flow and controlled floods" have been arranged for, and (iii) "the proposed river hydraulic model and outcomes of the Environmental Monitoring Plan will permit [sic] to optimize the required controlled flow." All of these assurances are baseless. 
The EIB stated in its 'Independent Review' that "the technical baseline for the estimation of the flood level is extremely limited and further hydrological and hydraulic investigations are necessary...". A similar point was made by the report when it stated, "It is actually not possible to evaluate the effectiveness of such a mitigation measure without a scientific detailed survey which will determine what is required to obtain successful results from flood recession cultivation."

The GOE suggests a "suitable environmental flow" from which controlled flow calculations have been designed. According to EEPCO, "The proposed river hydraulic model and outcomes of the Environmental Monitoring Plan will permit [it] to optimize the required controlled flow."

The value proposed is entirely inadequate for sustaining traditional artificial flood systems along the river's waterside flats and within the modern delta for the indigenous communities' continued survival within the lowermost basin, as the EIB consultant points out and ARWG physical scientists concur. The necessarily strongly increased figure would be would have to be based on data not yet even collected or analyzed.

- Whatever artificial floodwaters the GOE would release from the reservoir would be highly compromised if not entirely consumed by the large-scale irrigated agricultural enterprises downstream. Since the GOE downstream assessment omits any account of these enterprises it is not possible to accurately assess the abstraction of waters that would be required for the commercial operations but it is clear that this would be a massive removal of essential flow. The EIB inadvertently makes this point in labeling the GOE's planned releases from the dam wholly inadequate - even though the bank assessment omits consideration of abstraction for the irrigated systems. It is striking that the EIB report, like the 2010 AFDB assessment, ignores the GOE's own disclaimers of a sustained artificial flood program (see below).

- Finally, artificial flooding even minimally sufficient in order to sustain recession agriculture, grazing and fisheries locales downstream would likely be highly destructive for expensive and fixed irrigation works along the lower Omo River. Hundreds of thousands of hectares of large-scale irrigation systems are involved along the lower Omo River are planned by the GOE - many of which are already under construction (see above chapters and Chap. 7). This point was first raised in the main text of the 2010 EIB assessment. This argument against substantial controlled flood releases is partially responsible for the failure of implementation of 'promised' controlled floods in much of Africa.

In sum, the bare survival of hundreds of thousands of indigenous people would be destroyed - a crisis only worsened by dam-dependent, irrigated agricultural enterprise abstraction of remaining Omo River flow. This major reality is acknowledged by the EIB (2010) impact assessment, but only obscurely in the report's text while omitted in its Summary and Conclusion. These points are emphasized in the discussion of development bank assessments below.

\section{Multilateral Development Banks and the 'Complicity Treadmill'}

At its core, the relationship between multilateral development banks and the global consulting industry is one of reciprocity. In return for basic compliance with development bank interests and parameters for impact assessment, global industry consultants are rewarded with lucrative contracts and favorable status in future bidding processes. This enables the development banks to maintain relationships with 'reliable' contractors for subsequent projects and simultaneously satisfy their operational requirements for 'open bidding' and 'arms length' assessment. Meanwhile, the global consulting industry firms and individuals concerned can maintain their professional standing as 'independent' analysts - even among many non-governmental organizations critics and the concerned public.

This reciprocal relationship amounts to a 'contract treadmill' that can persist for decades. Chapter 1 describes much of the basis for this treadmill emerging from the progression of institutions and political relations involved in river basin development within Ethiopia. ${ }^{7}$ The connection between development banks, global industry consulting firms and individuals involves both explicit and implicit agreements, or 'understandings,' regarding boundaries and approaches for impact

\footnotetext{
${ }^{7}$ Similar reciprocal relationships exist between executive offices of (African) states and major bilateral aid agencies, on the one hand, and global consulting firms and individuals, on the other.
} 
assessment. Contract Terms of Reference, or 'Scoping' and 'Bounding' specifications, set parameters such as geographic extent and emphasis on-or de facto exclusion of-particular environmental and socioeconomic impact dimensions in assessments. Implicit 'understandings' are equally important in shaping of assessment content and conclusions, particularly in capital-intensive projects such as river basin developments.

Together, these explicit and implicit directives lead to assessments by global consulting industry firms and individuals that provide 'complicity with comment'-lending credibility to the assessment process without fundamentally questioning the projects in question.

Development bank and other policymakers rely on summary sections of assessments, including Executive Summary, Conclusions, and Recommendations. It is commonplace that policy-makers and their staff policy officers and their staff only peruse main texts of assessments and key reports in order to confirm their apparent 'empirical' character or for some highly specific purpose. Consequently, brief mention or 'notation' of major problems embedded in the main text of assessments, are seldom substantively considered. Even problems mentioned in the summary and conclusion sections are easily passed over unless their significance is prominently stated.

Global consulting industry representatives commonly downplay impact problems potentially severe enough to merit delay or halt of the project at hand. Even the most destructive environmental and socioeconomic impacts predictable for a project are frequently raised only as 'suggestions' for 'further study' or inclusion in alleged mitigation or monitoring efforts. Finally, consultants acknowledge major impacts inconspicuously in the often highly technical text of assessments but omit or barely mention in Conclusion or Executive Summary section.

These different means of minimizing negative impacts are pervasive in the GOE, EIB and AFDB assessments of the Gibe III dam - as is the avoidance of the contentious issue of dam-enabled major irrigated agricultural enterprises planned, information about which was fully accessible to the consultants. ${ }^{8}$

$>$ The European Investment Bank and African Development Bank, while considering requests from GOE for Gibe III project funding, each contracted long-established global industry consultants for 'independent' impact assessments of the dam. The EIB extended a contract for a review (EIB 2010) of the GOE's environmental and socioeconomic downstream assessment - relating only to Ethiopia. The contract was awarded to the France-based global firm, Sogreah. For its part, the AFDB limited (by its Terms of Reference) its impact assessment to Kenya's Lake Turkana region, even though it had previously funded the most recent Master Plan for the Omo basin (Woodroofe and Associates 1996). The AFDB contracted for two separate impact assessments for the Lake Turkana region - the most notable of which was for the dam's hydrological impacts on the lake, including its water level and fisheries (AFDB 2010). ${ }^{9}$ This contract was awarded to a former senior manager and executive for 26 years with the Nairobi-based global firm, Gibb Africa. ${ }^{10}$ The second assessment was for the dam's socioeconomic impacts (AFDB 2009).

There was no apparent link between the AFDB's environmental (Lake Turkana) and socioeconomic assessments, nor between these assessments, on the one hand, and lake level drop caused by the Gibe III dam and linked developments, on the other. The hydrological assessment (AFDB 2010) is by far the one referred to by government and development agencies. However, the socioeconomic assessment has been largely ignored in policy statements and documents - likely for reasons outlined below.

Both Sogreah and Gibb Africa (formerly, Sir Alexander Gibb and Partners) had been engaged in Ethiopian river basin development since the Awash Valley developments in the 1960s. As outlined in Chap. 2, both firms had received contracts from international development bank and major bilateral agencies for river basin and related water resource development projects that totaled hundreds of millions of dollars from major aid agencies.

\footnotetext{
${ }^{8}$ As the earlier sections of this chapter detail, 'downplaying' also occurs as straightforward falsification and misrepresentation — both of which are described above to be pervasive in the GOE's assessment of downstream impacts (GOE 2009b).

${ }^{9}$ Unless otherwise specified, the AFDB assessment referred to below is the 2010 AFDB assessment of Gibe III impacts on the hydrological conditions of Lake Turkana, rather than the 2009 AFDB socioeconomic assessment.

${ }^{10}$ Shortly before signing a contract with the AFDB for the hydrological assessment of the Gibe III dam, this consultant joined a new consulting group of experienced individuals: Nairobi-based Water Resource Associates.
} 
The fragmentation of the Gibe III dam assessments into separate country approaches basically defined away, by simple Terms of Reference, consideration of the worst impact zone in terms of human lives at risk, namely, the transboundary region.

There are a number of shared failings of the EIB (2009) and AFDB (2010) assessments. Beyond the longstanding contract history with development banks and other key aid agencies and the obvious limitations by Scoping agreement with their client institutions, many of these failings can be traced to an uncritical view of GOE information and perspective or to the reality that these assessments were primarily 'desk studies' with brief field trips, rather than substantial field-based investigations. ${ }^{11}$ The key problems include:

- Failure to cite inadequate impact assessment parameters as defined in their own Terms of Reference (or Scoping/Bounding instructions) agreed upon with their respective clients- the EIB and AFDB.

- Failure to analyze the transboundary region, where the most intensive destruction of human life and environment by the Gibe III dam and associated development would be inflicted.

- Discounting of the major seismic threat documented for the Gibe III dam geological province, despite available data indicating a $20 \%$ chance of a 7-8 magnitude earthquake within fifty years, as detailed in Chap. 3. The EIB and AFDB assessments do not challenge the GOE's statements (nor those by the company constructing the Gibe III dam-the Salini corporation) that no evidence exists for a significant seismic threat to the Gibe III dam. Such statements are indefensible by any scientific reckoning.

The EIB consultant's response to the ARWG's 2009 reporting of data in support of serious seismic threat in the dam region —information expanded in this writer's subsequent report (Carr 2012) — was simply stated as:

"Some risk cannot be avoided".

The 2010 AFDB assessment referenced the EIB's stance, with this added 'suggestion':

It would be sensible for the EIA studies to evaluate the consequence of a dam-break situation, especially as the dam is being constructed in a seismically active zone and will store a massive volume of water equal to a depth of two meters on Lake Turkana.

- Failure to challenge the Ethiopian government's false assertions of 'disasters and 'uncontrolled flooding' by the Omo River, and particularly the GOE's falsification of catastrophic loss of human life and livestock. As described earlier in this chapter, no such phenomena have occurred. ${ }^{12}$ This major flaw in the assessments is closely related to the their failure to address the GOE's false assertions of "excessive evaporation" from overbank flooding by the Omo into vast floodplains - evaporation of waters that the GOE maintained "contribute to the current recession of Lake Turkana, and waters that would be "recovered" following the Gibe III dam, thus providing major water to Lake Turkana. In fact, no such broad flooding of these lands occurs since they are ancient floodplains, as noted earlier.

- Acceptance of GOE and Salini (the Gibe III's construction firm) assertions of a 'brief' reservoir filling period, without risk of water seepage leakage from the reservoir (GOE 2009b). ${ }^{13}$ Without reference to available literature contrary, the EIB consultant further contends that even if leakage from the reservoir were to occur, it would 'migrate back into the Omo basin' and flow to Lake Turkana. Despite the obvious major importance of the issue for the hydrologic impacts of the dam on Lake Turkana, the 2010 AFDB assessment concurs, stating:

\footnotetext{
${ }^{11}$ Like the 1996 AFDB-financed Master Plan for the whole Omo basin and the AFDB-supported 1990 Master Plan for Ethiopia's river basins in total, the 2010 EIB and AFDB assessments are primarily document studies, with limited field-based investigation The EIB, for example, reported 11 days field investigation between the Gibe III dam site and the lowermost end of the Omo basin.

${ }^{12}$ The 2010 AFDB consultant later questioned GOE claims of such destruction in two publication for the African Studies Centre at Oxford (Avery 2012, 2013). This point had been made by the ARWG in 2009 and again in = Carr 2012.

${ }^{13}$ The GOE (2009a) notes that food aid will be required for just "two years", when no flood will occur. No mention is made that adequate floods for recession agricultural plots would cease.
} 
In 2009, the reservoir area had not yet been studied due to the challenges of access (Salini et al., 300 GEO RSP 002A, 2007). However, studies have since been reported, and Salini remain of the view that there are no appreciable losses (Pers. Comm. Studio Pietrangeli, 2010). This view has not been disputed by others conducting reviews, such as Sogreah (Sogreah, 2010), and if there are any losses, the topography dictates that the losses will feed back into the Basin and will not be lost.

There is ample geological literature and observation in the Gibe III region (see Chap. 3) documenting the highly fractured volcanic rocks, including basalts — conditions for strong leakage from the reservoir. Furthermore, statements of "no loss" of even leaked waters because of movement back into the Omo basin are meaningless - certainly from the standpoint of human life and ecological conditions in the lowermost basin and Lake Turkana. Seepage waters would require multiple decadesperhaps centuries, according to ARWG geologists - to migrate the hundreds of kilometers to the lowermost basin and Lake Turkana. This 're-balancing' would obviously have no impact on the human devastation already having occurred.

- Agreement with the GOE's (2009b) false statement that a lowering of Lake Turkana's level by 1.8 m "during the reservoir filling" period" would be "insignificant" since this decrease in lake level is "within the annual fluctuation of the lake. $" 14$ In fact, the drop in lake level would be in addition to, not within, whatever annual fluctuation occurs. Even the first two meters of lake level drop-with its corresponding cessation of Omo River flooding of vast areas along the lowermost river and within the modern delta — would have disastrous impacts on the human communities already facing major malnutrition and health crises.

$>$ It is possible to cite specific EIB and AFDB (2010) assessment patterns that reflect the widespread practice of complicity on the part of the global consulting industry (GCI) with their client government and development agency institutions. This complicity takes some particularly common forms, partially noted above. ${ }^{15}$ They include:

- Agreeing to (sometimes even drafting) Terms of Reference (or Scoping) for assessments-terms that exclude consideration of possible or even likely major human and environmental impacts: for example, impacts on resource accessibility, local survival systems and preexisting livelihood stresses, as well as the critical matter of cumulative effects of actions - in the case of the Gibe III dam, cumulative effects of the dam, irrigated commercial agriculture and the hydroelectricity export transmission system.

- Offering 'critical' remarks regarding impacts of projects, but as suggestions for (optional) 'future study,' as 'considerations' for monitoring or mitigation of completed projects or other optional courses of action.

- Noting a destructive impact of major proportion without identifying its significance or the necessity of resolving the matter prior to inception or continuance of the project in question.

- Identifying serious, even life threatening or potentially disastrous impacts-in detailed or highly technical text within reports or assessments, rather than in clear form in Conclusions. Summary or Recommendation sections.

Table 6.3 summarizes these and related patterns in the 2010 EIB and 2010 AFDB reports.

The EIB assessment presents a combination of content ranging from all-encompassing positive statements regarding the 'benefits' of the Gibe III dam to the highly specific criticisms of GOE (2009b) methodologies. This statement in the report's summary, for example, exemplifies the overall positive evaluation of the project by the EIB consultant:

The ESIR Consultant considers the Gibe III project ... to initiate the economic development of the Lower Omo, one of the least developed regions of Ethiopia. It is recommended that any financial support to Gibe III development is closely linked to the simultaneous socio-economic development of the Lower Omo region, in order to maximize the benefits from the river flow regulation.

\footnotetext{
14، The first filling of the Gibe III reservoir will have a limited incremental impact on the lake's natural water level fluctuations. It is expected that there will be a lowering of the water level by about $1.8 \mathrm{~m}$. This value is close to the annual fluctuations of water level in the lake, which is around $1.5 \mathrm{~m}$, and well within the inter-annual fluctuations observed in the past (EIB 2010)."

${ }^{15}$ Between the two AFDB assessments, this failing is most evident in the 2009 socioeconomic assessment.
} 
Table 6.3 European Investment Bank and African Development Bank impact assessments

\begin{tabular}{|c|c|c|c|c|c|}
\hline $\begin{array}{l}\text { Bank } \\
\text { Impact } \\
\text { Report }\end{array}$ & $\begin{array}{l}\quad \text { I } \\
\text { Suggested } \\
\text { mitigation or } \\
\text { monitoring } \\
\text { measures }\end{array}$ & $\begin{array}{l}\quad \text { II } \\
\text { Suggested studies or } \\
\text { reviews of issues or } \\
\text { potential problems }\end{array}$ & $\begin{array}{l}\quad \text { III } \\
\text { Identification of } \\
\text { definite problem } \\
\text { without analysis of } \\
\text { significance }\end{array}$ & $\begin{array}{l}\quad \text { IV } \\
\text { Identification of } \\
\text { critical problem } \\
\text { without assertion of } \\
\text { urgency re: possible } \\
\text { major destruction }\end{array}$ & \begin{tabular}{|l}
\multicolumn{1}{c}{$\mathrm{V}$} \\
Identification of \\
critical issue \\
threatening major \\
destruction - \\
needing resolution \\
prior to project $^{\text {continuance }}$
\end{tabular} \\
\hline EIB & 21 & 16 & 17 & 8 & 0 \\
\hline AFDB & 3 & 19 & 10 & 2 & 0 \\
\hline
\end{tabular}

Information is based on summary sections of both reports (Executive Summary, conclusions, recommendations) in 2010 EIB and AFDB assessments

${ }^{\mathrm{a}}$ In the case of the Gibe III dam impact assessments by the GOE, EIB and AFDB, all such efforts were initiated only well after project

The AFDB's assessment of 2009, with Terms of Reference to identify the socioeconomic impacts of the Gibe III dam in the Lake Turkana region, is rife with analytical misinformation, inconsistencies. This assessment fails to undertake a substantive investigation of even the most basic aspects of pastoral, mixed pastoral/fishing and fishing livelihoods in the Turkana region, let alone the potential impacts of the Gibe III dam—or its linked irrigated agricultural enterprises—on these systems. The report blatantly asserts the Gibe III's overall "benefits" to residents in the lake region.

The EIB report identifies at least eight major problems predictable from the Gibe III dam development, including the virtual absence of baseline data for Omo River flow volume and river inflow to Lake Turkana, inadequate consultation with local communities, and inadequate 'compensation' for residents of the lower Omo basin. However, the report stops short of asserting that any of these are key issues necessitate resolution prior to continued dam building and operation (Table 6.3).

At least seventeen additional problems of significance are identified, though inconspicuously, in the EIB report. Most significant among them are the following.

- Absence of a sound management plan and the failure to substantively evaluate 'compensation' for the region's resident population.

- Fundamental conflict between power generation at the Gibe III dam and the high opportunity cost of releases of water for controlled flooding downstream.

- Likely occurrence of serious disease outbreaks downstream from the dam.

- Drying out of lands within the Omo delta and low riverside flats, where flood recession agriculture would be eliminated (see below).

- An 8-10-km retreat of Lake Turkana's northern shoreline — as a result of the radical reduction of Omo inflow to the lake (Fig. 5.2).

- Possible violent conflict among ethnic groups within the Ilemi region. 
The EIB report fails to draw the obvious implications of such problems for the overall impact of the Gibe III project, even when some of them clearly spell disaster for the resident population and the region's environmental integrity. The main exception to this pertains to the report's recognition of the loss of recession agriculture, due to effects of the dam.

In the Lower Omo plain, the construction of the Gibe III dam will have significant and direct impacts on the reduction of cultivated land on the riverbanks and flooded areas (flood recession agriculture)...Approximately 67,600 people depend to some extent on flood recession agriculture. (EIB 2010)

Even these statements are fully inconsistent with other assertions in the report. For example, the EIB apparently relies on GOE 'estimates' and assertions of 'limited indigenous reliance' on flood recession agriculture - therefore, limited vulnerability of the indigenous to livelihood systems to destruction from the Gibe III dam. The EIB quotes the GOE's false statement, shown below, without comment:

Only for Karo people where livestock is less significant might recession agriculture constitute the main source of ivelihood. [Emphasis added.]

In contradictory fashion, the EIB report references GOE estimates of 20,000 households within the delta that are practicing flood recession agriculture ('and cropping'), yet states elsewhere:

This means that 100,000 people could be affected in the delta alone.

For Dasanech communities along the Omo River, the loss of flood recession agriculture would have disastrous consequences. Yet the EIB report repeatedly asserts that any loss of livelihood from elimination of flood recession agriculture could be "compensated" or "offset" by rainfed agriculture - a patently false statement. Even brief conversation with Dasanech residents or ecological ground reconnaissance in the lowermost basin and delta region would reveal-firstly, that there is no 'rainfed cropping' in the region (in contrast with the Mursi region upstream), and secondly, that multiple thousands of households depend on flood recession agriculture for their survival because their pastoral economy has been dismantled in recent years. ${ }^{16}$

A dominant feature of the EIB assessment's summary section is its inclusion of at least sixteen 'suggestions' for further study or review - few if any of which have been carried out since the report was released. Some of these suggestions pertain to impacts identified above; others are major issues that most critics would view as essential to resolve prior to conceptualizing the dam, and certainly before actually constructing and operating the dam. The EIB report suggests various studies studies, including of Omo River flow volume and inflow to Lake Turkana, the technical feasibility of a controlled flood program, livelihood development plans for the indigenous population, the socioeconomic and ecological character of the delta, indigenous recession agricultural systems and riverine zone biodiversity. None of these are suggested as essential to the planning or implementation of massive development in the basin, when the reality is that virtually all of them are.

Offsetting any such problems noted by the EIB are its assertions of 'positive' Gibe III dam outcomes for local residents and for the ecology of the lower basin (Table 6.3). The report offers at least twenty-one positive statements about the Gibe III project and its objectives, as well as GOE intentions and efforts to address local problems. ${ }^{17}$ The vast majority of these statements are unfounded, and the likelihood of GOE adoption of the numerous mitigation 'suggestions' is understood to be miniscule.

The EIB assessment repeats GOE's assertions that its planned irrigation and canal works in the lowermost Omo basin will be for "social development" projects - mainly, small-scale irrigated agriculture for pastoralists and distribution of social services (GOE 2009b). The opposite was already occurring, however, even by the end of 2009 and early 2010 - namely, the expropriation of major resource and village areas along the river for the establishment of irrigated, large-scale government as well as private farm enterprises. Desperation was already widespread, especially among the Dasanech.

\footnotetext{
${ }^{16}$ As detailed in Chap. 7, Dasanech villagers throughout the region consistently stated to South Omo/North Turkana (SONT) researchers that no GOE or other individuals had been to their villages for information about household members and population, floods, recession agriculture or any other activities.

${ }^{17}$ Although the GOE's violations of EIB funding procedural requirements may well have raised a roadblock for the bank to fund the dam project directly (a parallel situation with the AFDB and the World Bank), there are different interpretations as to why EIB funding did not actually materialize. Whatever the decision of the EIB would have been, the Ethiopians reached an agreement with the Chinese for just under USD 500 million for construction (see Chap. 1).
} 
By comparison with the EIB, the AFDB has been far central in the rationalization of the Gibe III development, in several regards. These include its financial and technical support for::

(i) River basin development master plans and feasibility studies of dam and irrigated agricultural development in the Gibe-Omo basin, from 1990 through 1996.

(ii) Impact assessments for the Gibe III project (2009/2010) - reports largely complicit with the development.

(iii) Financial support and legitimation of the major transmission line for exporting electricity Ethiopia to Kenya and the broader eastern Africa region - a line including Gibe III electricity by all GOE accounts, despite AFDB and World Bank disclaimers.

The development bank's socioeconomic impact assessment (AFDB 2009) lacks an even minimally acceptable livelihood description and analysis; various failings of the report are dealt with in Chap. 9. The AFDB socioeconomic consultants apparently viewed their task as promoting the Gibe III dam project, as their own descriptions suggest. However, the assessment does briefly note Turkana community opposition to the dam because of its likely destruction of the lake and its fishery - and even to threats of direct action by local leaders. Nevertheless, the consultants refer to their role as one of emphasizing project 'benefits' to local residents.

The AFDB 2010 hydrological assessment is the primary one referred to by GOE, development bank and other officials. It presents a largely complicit with the project. As indicated in Table 6.3, it generally states concerns as 'suggestions' for studies or reviews, or as notations for possible monitoring or post-operational mitigation. The report's major reservation about the Gibe III dam project, stated only hypothetically, pertains to 'possible' irrigation schemes upstream. (As noted earlier, the AFDB consultant produced two later reports for the African Studies Centre at the University of Oxford (Avery 2012, 2013) that took a far more critical view of the impacts of irrigated commercial agricultural development on Lake Turkana-predicting, in fact, likely major destruction of the lake.

The 2010 hydrological assessment does identify some significant problems with the GOE's impact assessment of the downstream Omo riverine zone within Ethiopia (GOE 2009b), such as in its statement, "Positive impacts on the lake's hydrology have been claimed, but there was no basis for these claims." Other problems with the GOE's assessment that are identified in the AFDB report include: the absence of Omo flow volume and lake inflow baseline data - for which the AFDB review lays out an alternative method of calculation; predictable Omo River incision and water table drop, sediment capture and buildup at the dam, and impact of flood regime changes on fish breeding in the lake. ${ }^{18}$

Beyond the deficiencies identified above as in common for the AFDB and EIB reports, other major problems exist in the 2010 AFDB hydrological assessment.

(i) Rather than recognizing the transboundary character of the Omo River itself, with its terminus within Kenya's national borders (Figs. 1.2 and 1.3), the AFDB report repeatedly asserts the river to be only within Ethiopia. For example, the Executive Summary states:

The lake is almost entirely within Kenya, whereas the Omo River is entirely within Ethiopia.

Rather than acknowledge the transboundary nature of the Omo River itself, the AFDB report asserts only that the effects of reduced flow (unspecified as caused by the dam or irrigation) would impact Kenya, so that "management of the Omo Basin and lake water resources presents transboundary challenges"- presumably with management techniques after dam operations have been launched.

\footnotetext{
${ }^{18}$ A prediction of Lake Turkana's likely drop in level during and following the Gibe III reservoir-fill, by an ARWG physical scientist long familiar with the regioni, is presented in Chap. 5 and subsequent chapters.
} 
The matter of the Omo's terminus with Kenya, making it an international river, is obviously of major political significance in any economic development affecting the river's delivery of water to neighboring countries and must be negotiated with those countries' governments-prior to project approval or inception. This point reflects both international principles and Ethiopian regulations. The AFDB assessment skirts any explicit recognition of this reality. ${ }^{19}$

(ii) Nearly all of the concerns raised in the 2010 AFDB assessment summary sections take the form of 'suggestions' for further study or review, mitigation or monitoring, as (Table 6.3) indicates. Many of the 19 studies or reviews that are suggested in AFDB summary sections involve issues that most analysts would consider fundamental to even a minimally adequate impact analysis. These require resolution prior to the project's undertaking. Because the dam was already under construction for nearly three years by the time the AFDB assessment was produced, such suggestions clearly remain discretionary on the part of project developers and they presumably were meant to be undertaken during or after project completion and operation (see Table 6.3). For example, studies or reviews are suggested for bathymetric studies of the lake, hydrologic measurement, flooding patterns of the river, irrigation utilization of the river, fisheries status of the lake, calculation of the 'economic value' of the lake, socioeconomic studies, and 'integrated basin environmental and socioeconomic assessment,' and dam 'breakage.'

(iii) The AFDB 2010 assessment fails to deal with the predictable 8-10-km retreat of Lake Turkana's northern shoreline during Gibe III reservoir filling period (EIB 2010) and the consequences of this retreat for major fish reproductive habitats there. Such radical change spells disaster for hundreds of thousands of Dasanech and Turkana residents who depend on the northern lake's resources for their survival. The absence of the AFDB report's consideration of such a retreat is particularly disturbing in view of its recognition of the importance of the Omo's annual flood pulse of fresh water, sediment and nutrient input to the northern end of the lake.

(iv) The AFDB assessment erroneously and repeatedly describes the extensive irrigation agriculture development along the Omo River as a separate phenomenon from the Gibe III dam. The fundamental dependence of the irrigated farms on the Gibe III dam's regulation of the Omo River is essentially denied, or downplayed, as evidenced by these statements:

"This hydrological study has demonstrated that with the potential abstractions that might be implemented, the lake could drop up to $20 \mathrm{~m}$. This is not attributable to Gibe III..." [Emphasis added.] "Irrigation abstraction is not a project component of the Gibe III project, as the dam is developed solely to generate power, but indirectly, the regulated flow sequence from the dam is expected to stimulate small-scale irrigation". [Emphasis added.]

While the latter statement is technically accurate, it omits the reality that the dam's hydroelectric potential and the Omo Valley's possible irrigation agriculture, including large-scale commercial operations - were long considered integrally by development interests.

The 2010 EIB impact report references GOE information (see below) regarding irrigation plans in its consideration of irrigation feasibility potential in the lower basin, and report includes a GOE map indicating major irrigation areas planned (see chap. 7). The GOE has openly solicited international agribusiness and related industrial investment in the Omo basin prior to and during preparation of the EIB and AFDB assessments.

Since feasibility studies and planning (even some construction) of large-scale irrigation infrastructure were undertaken well before the AFDB assessment and were, in fact, referred to by its author, planning for both the hydroelectric dam and its linked irrigated agricultural enterprises was certainly known to the AFDB consultant.

\footnotetext{
${ }^{19}$ The AFDB does quote, but without comment, the 1996 Master Plan for the Gibe-Omo river basin: “...This means that in the international context a bilateral agreement should be reached between the two countries (Kenya and Ethiopia) before either country changes the natural flow of the river...Any major change in the river's regime as, for instance, by the construction of a dam for the development of hydro-power, or, more significantly, by the development of large-scale irrigation in the south of the basin, would be almost certain to raise issues internationally...".
} 
The development banks had actually supported various aspects of planning for river regulation and large-scale irrigated agriculture in Ethiopian river basins for decades. In the case of the AFDB, the bank had directly funded two desk studies of major policy importance. One of these was the 1990 Master Plan for all Ethiopian river basins, prepared by the global consulting firm, WAPCOS (see Chap. 2). The other - contracted to Woodroofe and Associates a few years later for USD 6.1 million - was the 1996 Master Plan for the Gibe-Omo River Basin, which estimated both the basin's potential hydrodam electricity and irrigation agricultural development.

The GOE's 2009 downstream impact assessment formulated three types of irrigation:

- Small-scale 'settlement' agriculture,

- Small-scale commercial irrigated farms, and

- Large-scale irrigation farms-i.e., over 7200 ha (cotton and sugarcane plantations).

Two additional statements within the AFDB 2010 impact assessment are sufficient to illustrate the report's failure to link the Gibe III dam and major irrigation systems and to directly address the seriousness of the combined dam-irrigation effects on the indigenous population.

"If irrigation development proceeds as planned in the Omo Basin, the lake will diminish, as will biomass and fisheries. Whether this is of consequence should be the subject of a separate study and consultations with the Kenyan Government and stakeholders, and should be based on a proper economic evaluation of Lake Turkana and its resources." [Emphasis added.]

"The biggest impacts can be expected to arise from Ethiopian Government plans for large scale irrigation within the Basin. These have not been studied in this Report, but they must be taken into account at some point, as it will be futile to disregard developments in the Basin as a whole as they affect mitigation measures. As developments are inevitable to cope with rising population pressure and food security needs, a balanced view needs to be agreed upon between Kenya and Ethiopia, through detailed studies and dialogue, on what environmental impact is acceptable, and on what mitigation measures can be adopted, and how they will be managed. This process has already begun." [Emphasis added.]

In reality, major scale irrigated agricultural enterprises planned or under construction downstream from the Gibe III dam are clearly dam enabled enterprises, not 'unrelated' phenomena. Among numerous linkages are these closely related ones:

- Large irrigation systems, commonly for monocrops and high chemical use-require predictability of water and calibration of cropping phases - predictability that can only be provided by regulation of the river flow volume and its periodicity.

- Irrigation infrastructure cannot accommodate wide fluctuations of the river's natural state.

Linkages between river regulation by major dam construction and large-scale irrigated agricultural enterprises are well-documented in developmental policy and economic and scientific literature concerning drylands Africa. They have been in play throughout the decades of 'modern' Ethiopian river basin development, beginning with that nation's first irrigated agricultural schemes and major (at the time) dam development —in the Awash Valley.

Since large-scale irrigated agricultural development along the lower Omo River is dependent on the river's regulation by the Gibe III dam, these two developments have a causative connection. This matter is discussed in Chap. 10, along with the critical matter of human rights violations being committed. 


\section{Literature Cited}

African Development Bank (AFDB). 2009. A. S. Kaijage, N. M. Nyagah, Final Draft Report, Socio-economic analysis and public consultation of Lake Turkana communities in Northern Kenya, Tunis.

African Development Bank (AFDB). 2010. S. Avery, Assessment of hydrological impacts of Ethiopia's Omo Basin on Kenya's Lake Turkana water levels, Final Report. 146 pp.

Africa Resources Working Group (ARWG). 2009. A commentary on the environmental, socioeconomic and human rights impacts of the proposed Gibe III Dam in the lower Omo River Basin of Southwest Ethiopia. http://www.arwg-gibe.

Avery, S. 2012. Lake Turkana and the lower Omo: hydrological impacts of Gibe III and lower Omo irrigation development, Vols. 1-2. African Studies Centre, University of Oxford.

Avery, S. 2013. What future for Lake Turkana? The impact of hydropower and irrigation development on the world's large desert lake. African Studies Centre, University of Oxford.

Carr, C.J. 1977. Pastoralism in crisis: the Dassanetch of Southwest Ethiopia. Chicago: University of Chicago Department of Geography Papers. (.90), 319 pp.

Carr, C.J. 1998. Patterns of vegetation along the Omo river in southwest Ethiopia. Plant Ecology 135(2): $135-163$.

Carr, C.J. 2012. Humanitarian catastrophe and regional armed conflict brewing in the border region of Ethiopia, Kenya and South Sudan: The Proposed Gibe III Dam in Ethiopia, Africa Resources Working Group (ARWG), 250 pp. https://www.academia.edu/8385749/Carr_ARWG_ Gibe_III_Dam_Report.

Government of Ethiopia (GOE). 2009a. Ethiopian electric power corporation (EEPCO), CESI, mid-day international consulting engineers (MDI), Gibe III hydroelectric project, environmental and social impact assessment, Report No. 300 ENV RC 002C Plan.

Government of Ethiopia (GOE). 2009b. Ethiopian electric power corporation (EEPCO), agriconsulting S.P.A., mid-day international consulting, level 1 design, environmental and social impact assessment, additional study of downstream impacts. Report No. 300 ENV RAG 003B.

Government of Ethiopia (GOE)., and Ethiopian Electric Power Corporation (EEPCO). 2010. Environment and social issues related to Gibe III hydroelectric project, GIB HEP Office. http://ethiopianembassy.org/pdf/giveiihydroelectricproject.pdf.

Kinde, S., and S. Engeda. 2010. Fixing Gibe II—engineer's perspective. http://www.digitaladdis.com/sk/Fixing_Gilgel_Gibe_II.pdf.

Thomas, G.A., and K. DiFrancesco. 2009. The heritage institute for the world bank. Final report, rapid evaluation of the potential for reoptimizing hydropower systems in Africa.

USDA, United States Department of Agriculture. 2006. MODIS satellite imagery August 11, 2006; August 21, 2006.

Woodroofe, R., and Associates, with Mascott Ltd. 1996. Omo-Gibe river basin integrated development master plan study. Final Report. I-XV Vols.

Open Access This chapter is distributed under the terms of the Creative Commons Attribution-NonCommercial 2.5 International License (http:// creativecommons.org/licenses/by-nc/2.5/), which permits any noncommercial use, duplication, adaptation, distribution and reproduction in any medium or format, as long as you give appropriate credit to the original author(s) and the source, provide a link to the Creative Commons license and indicate if changes were made.

The images or other third party material in this chapter are included in the work's Creative Commons license, unless indicated otherwise in the credit line; if such material is not included in the work's Creative Commons license and the respective action is not permitted by statutory regulation, users will need to obtain permission from the license holder to duplicate, adapt or reproduce the material.

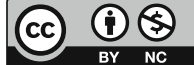

